\title{
Physiological responses and specific fatty acids composition of Microcystis aeruginosa exposed to total solar radiation and increased temperature
}

\author{
Florencia de la Rosa ${ }^{1,2,3} \cdot$ Marleen De $\operatorname{Troch}^{4} \cdot$ Malanga Gabriela ${ }^{5} \cdot$ Hernando Marcelo ${ }^{6,7}$ (i)
}

Received: 6 January 2021 / Accepted: 26 May 2021

(c) The Author(s), under exclusive licence to European Photochemistry Association, European Society for Photobiology 2021, corrected publication 2021

\begin{abstract}
The combined effects of increased temperature and solar ultraviolet radiation (UVR, 280-400 nm) on M. aeruginosa cultures was analyzed in terms of cell abundance, reactive oxygen and nitrogen species (ROS/RNS), antioxidant activity of catalase (CAT), superoxide dismutase (SOD), glutathione $S$ transferase (GST), fatty acids (FA) content and lipid damage. After 12 days exposure to high temperature $\left(29^{\circ} \mathrm{C}\right)$, cells were exposed to solar UVR (4 h). Ultraviolet-B radiation (UVBR, 280-315 nm) resulted into low cell abundance, high ROS/RNS and a significant increase in SOD activity with no changes in GST and a decreased CAT activity at control temperature $\left(26^{\circ} \mathrm{C}\right)$. A significant increase in the analyzed enzymatic antioxidants was observed at $29^{\circ} \mathrm{C}$, as a response to avoid ultraviolet-A radiation (UVAR, 315-400 nm) damage. The relative abundance of $\omega 6$ FAs was not affected by UVAR while $\omega 3$ FA were highly sensitive at $29^{\circ} \mathrm{C}$ but unsaturated fatty acids (UFA) peroxidation did not occur. The differential response in FA to high temperature and UVAR results in differences in lipid damage and antioxidants. It was evident that selected UFAs (mostly $\omega 6$ ) play an important role in high temperature adaptation in addition to enzymatic antioxidant increased activity shifting the temperature growth from 26 to $29^{\circ} \mathrm{C}$. Thus, cell death and UFA damage were avoided at high temperature and low solar irradiance thanks to an increased enzymatic antioxidant activity.
\end{abstract}

\section{Graphic abstract}

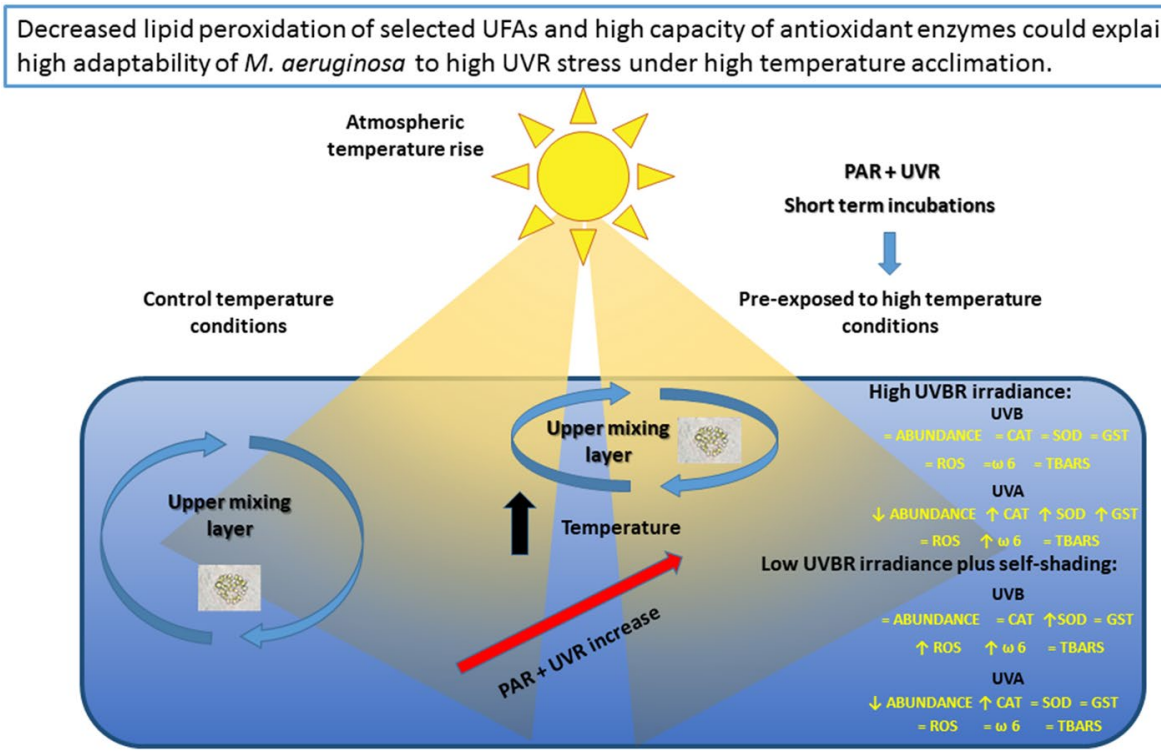

Keywords Fatty acids $\cdot$ Oxidative stress $\cdot$ Microcystis aeruginosa $\cdot$ Temperature $\cdot$ UVR

Extended author information available on the last page of the article 


\section{Introduction}

Due to greenhouse gas emissions, an increase of about $0.6{ }^{\circ} \mathrm{C}$ in the annual average surface planet temperature was registered in the last 30 years [1]. In addition to the increased temperature, another atmospheric problem is the decrease of stratospheric ozone as a consequence of the chlorinated fluorocarbons (CFCs) [2]. According to Bais et al. [3], this ozone problem will persist for the next decades and will probably spread in different areas of high latitudes [4]. However, according to latest observations, Bais et al. [5] suggested that the combined effects of changes in ozone, aerosols, greenhouse gases, clouds, and reflectivity will determine future levels of solar UVB radiation (UVBR) at the Earth's Surface with ozone values stabilized at the last years and with projections of a soon recovery.

As a consequence of the reduced ozone layer, the amount of solar UVBR that reaches the Earth's surface increased [6]. This decrease in the ozone layer and consequent significant increase in UVBR has been registered mainly in Polar Regions and at mid-latitudes [7].

Future changes in ozone concentration will depend on the changes in solar cycle, temperature dynamics and climate $[5,8]$. However, given the stabilizing and recent evidence for recovery of stratospheric ozone, climate change and other environmental variables are now the most important factors changing exposure to UVR in aquatic ecosystems. Both UVBR and UVAR cause deleterious effects on the physiological parameters of phytoplankton and other aquatic organisms [9]. Global warming enhances stratification of water column in lakes depends on their morphometry and decreases with larger wind speeds [10]. The organism exposure to solar UVR may be regulated by changing the position in the water column [11]. According to certain variables dependent on climate change, the depth of the mix layer can be variable, modifying the phytoplankton exposure to solar radiation [12]. Furthermore, the presence of gas vesicles in some cyanobacteria species allow them to regulate their position in the water column [13]. Therefore, organisms from shallower depth could be exposed to increased solar UVR doses due to less light attenuation [14]. The organic matter present in the water column can attenuate the solar irradiance reducing the exposure dose of those organisms that are found deeper. The inorganic and organic particulate matter in water depend in part of human activities [15]. Thus, increased discharge of fertilizers in agriculture may contribute to increase the nutrient concentrations in lakes and rivers [16]. Consequently, high nutrients concentrations and high temperature could lead to harmful algal blooms (HABs), including those produced by cyanobacteria [17]. For example, Microcystis is a genus forming blooms and often causes serious problems in the management of water quality due to the production of toxins [18]. Cloud cover is another factor, which may affect UVR doses in surface waters and the phytoplankton occurring in it [5].

In addition to changes in surface mixed layer depth, temperature is another factor that controls the growth and productivity of phytoplankton by modifying the photosynthetic process [19]. Consequently, both atmospheric phenomena (increased temperature and UVR) affect in an indirect and direct way the structure and function of aquatic ecosystems and the physiology of the organisms that live there [20].

To monitor the response of aquatic organisms to environmental changes, fatty acids (FA) have been used as biomarkers [21]. The membrane fluidity is regulated by the FA composition of the membrane phospholipids [22] and as such will change in case of temperature change. Thus, the lipid composition of the membrane could be changed with an increase or decrease of the degree of FA unsaturation (referred to as homeoviscous adaptation, [23]). In cyanobacteria, the highest percentage of lipids is in membranes [24], with a high proportion of unsaturated fatty acids (UFAs) particularly polyunsaturated fatty acids (PUFA). To avoid damage under stress conditions, cyanobacteria modify the type and quantity of their cellular lipids [25]. The high amount of double bonds makes PUFAs highly sensitive to any attack by reactive species [26]. Thus, the lipid peroxides produced by reactive oxygen/nitrogen species (ROS/RNS) results in the formation of Thiobarbituric Acid Reactive Substances (TBARS) [27]. In addition to their use as biomarkers, PUFA are very important to promote human health and because of that, there is an interest in evaluating the environmental factors that favour its production in organisms, especially at the lower levels of the food web [28, 29].

Both microalgae and cyanobacteria need sunlight to carry out the photosynthesis process, increasing the probability of producing high cellular concentrations of ROS due to photosynthetic electron transport chain [30]. The stimulation of the metabolism due to an increased temperature [31] implies an increase in oxygen consumption, which could lead to an increase of ROS. The ROS produced could be singlet oxygen $\left({ }^{1} \mathrm{O}_{2}\right)$, superoxide anion $\left(\mathrm{O}_{2}^{-}\right)$, hydrogen peroxide $\left(\mathrm{H}_{2} \mathrm{O}_{2}\right)$ and hydroxyl radical $\left(\mathrm{OH}^{-}\right)$[32].The presence of ROS in cyanobacteria cells produces inhibition of growth [33], degradation of Chlorophyll-a (Chl-a) and damage of the photosystem II (PSII) [34]. The oxidation of the membrane-permeable non-fluorescent 2,7-dichlorodihydrofluorescein diacetate (DCFH-DA) has been used to detect the presence of several ROS and reactive nitrogen species (RNS) in biological media [35], with an increase in DCFHDA oxidation used as an indicator of oxidative stress. DCFH-DA was initially thought to be useful as a specific indicator for hydrogen peroxide, even though the reaction is not direct. However, it was already demonstrated that DCFH 
is oxidized by other ROS, including superoxide anion radical, hydroxyl radical, peroxyl, alkoxyl, hydroperoxyl and peroxynitrite that are products of normal metabolism [36]. The use of the oxidation of $2^{\prime}, 7^{\prime}$-dichlorofluorescein diacetate (DCFH-DA) was useful to demonstrate the presence of reactive species in different cyanobacteria exposed to UVR or increased temperature, including Microcystis aeruginosa [37-39]. In the interpretation of DCFH-DA results, it is important to keep in mind that incubations are performed in the dark so any oxidation that occurs is due to endogenously generated ROS, not those directly induced by UVR. Oxidative stress occurs when the concentration of reactive species exceeds the available antioxidant activity [40].

In cyanobacteria, proteins [41] and DNA [42] are the primary targets for UVR exposure and reactive species generation. Further, photosynthesis inhibition $[43,44]$ and morphological changes [43] will be generated. In comparison with UVBR, UVAR produces the highest damage in photosynthetic organisms due to highest irradiance level reaching earth and it does not depend on the thickness of the ozone layer $[45,46]$. It is well known that UVBR is more effective per energy unit [47] and also acts directly on DNA and proteins, meanwhile UVAR is thought to cause long-term photosensitized oxidation [48]. In addition, Hernando et al. [44] showed that different responses were activated in $M$. aeruginosa depending on whether the exposure is to UVAR or UVBR as well as the dose level. However, cyanobacteria have developed a great number of strategies to avoid or mitigate the reactive species damage using antioxidants as scavenger. These might be non-enzymatic such as ascorbic acid, glutathione and tocopherols as well as enzymatic such as superoxide dismutase (SOD), peroxidases, catalases (CAT) [49] and glutathione $S$ transferase (GST) [50]. Most of cyanobacteria studies that evaluate the effects of variables associated to climate change such as UVR and increased temperature, have not evaluate the combined effects of both variables.Changes in several external variables may not result in simple additive responses relative to those that occurred with only one variable [51]. Different changes in these variables can produce synergistic or antagonistic effects [52]. So far, few studies evaluated the interactive effects of these variables, which may act in synergistic or antagonistic way [53]. Giordanino et al. [54] found that an increased temperature prevents the trichome/chains reduction in Anabaena sp., Nostoc sp. and Arthorspira platensis. In addition, it also increases the photosynthetic recovery of Anabaena sp. and Nostoc sp. after UVR exposure. On the other hand, Gao et al. [55] found that increased temperature favours A. platensis cells that were previously damaged by UVR exposure.

Due to the potential toxicity of cyanobacteria and their ecological importance [56,57], the objective of the present study was to evaluate the combined effects of increased temperature and solar UVR on $M$. aeruginosa cultures. Their response in a lab experiment was evaluated for FA composition and lipid damage, reactive species concentration, enzymatic antioxidant activity (CAT, SOD and GST) and cell abundance. Our results will contribute to a better understanding of possible climate change effects on cyanobacteria and the potential changes in the toxicity of aquatic ecosystems used a source of drinking water in medium-latitude cities.

\section{Materials and methods}

\subsection{Experimental set-up}

The Microcystis aeruginosa strain CAAT 2005-3, was isolated from a river in the province of Buenos Aires, Argentina [58]. The M. aeruginosa culture was pre-adapted for 14 days at $26{ }^{\circ} \mathrm{C}$ under artificial light at a photon flux density of $30 \mu \mathrm{E} \mathrm{m}^{-2} \mathrm{~s}^{-1}\left(6.6 \mathrm{~W} \mathrm{~m}^{-2}\right)$ under 14:10 h light:dark photocycle in an incubator shaker (Model Satandard Infors Multitron). This irradiance was achieved with the addition of 2 Philips TL-D $18 \mathrm{~W}$ tubes secured by means of a wood to the upper part of the incubator. This irradiance was monitored daily with an ILT 950 spectroradiometer, International Light Technologies, Inc., USA. The cultures grew with shaker conditions and with the addition of BG-11 culture medium [59].

Once in the exponential growth phase (i.e., after 2 weeks), cultures were kept at the control experimental temperature $\left(26^{\circ} \mathrm{C}\right.$, " $\mathrm{C}$ ") or exposed, in independent triplicates, to $29^{\circ} \mathrm{C}$ ("HT") in two independent growth chambers.

After 12 days of growth at both temperatures and still in exponential phase, cells were exposed simultaneously to three solar irradiance treatments with initial addition of $10 \%$ BG-11 medium in $80 \mathrm{~mL}$ quartz tubes (path length: $25 \mathrm{~mm}$; length: $137 \mathrm{~mm}$ ). Prior to experimental incubations, cultures were pre-adapted to solar radiation in containers covered with UV cut-off filters followed by exposure to only PAR irradiance in an outdoor water bath with running water for control $\left(26^{\circ} \mathrm{C} \pm 1\right)$ and high temperature $\left(29^{\circ} \mathrm{C} \pm 1\right)$ for 1 day before to the irradiance experiments day. After this period, cells were exposed simultaneously to the following treatments:

(1) Cultures that received full radiation (UVBR, UVAR and PAR) (TUVR treatment)

(2) Cultures that received UVAR and PAR - tubes covered with UV cut-off filter foil (Montagefolie No. 10155099, Folex, Germany: 50\% transmission at $320 \mathrm{~nm}$ ) (TUVA treatment) 
(3) Cultures that received only PAR - tubes covered with an Ultraphan film (UV Opak, Digefra, Munich, Germany $-50 \%$ transmission at $395 \mathrm{~nm}$ ) (PAR treatment).

The spectra of the materials used in our experiments are described in Hernando and Ferreyra [60].

To determine the UVBR effects, the difference between TUVR and TUVA values for each parameter (FAs, TBARS, reactive species, enzymatic antioxidants and cell abundance) was calculated.

The $M$. aeruginosa culture was exposed to natural sunlight at Buenos Aires $\left(34^{\circ} 35^{\prime} \mathrm{S} ; 58^{\circ} 22^{\prime} \mathrm{W}\right)$ during spring sunny days (November 28 and 30, 2017). The cultures were exposed in two outdoor water bath at the same two preexposed temperatures $\left(26\right.$ and $29^{\circ} \mathrm{C}, \pm 1{ }^{\circ} \mathrm{C}$ ), using running tap water at stable controlled temperatures during the entire incubation and monitored every $15 \mathrm{~min}$. The three replicates tubes for each treatment and at each temperature, were placed in a black anodized aluminium racks and in two black plastic water bath that were painted black on the inside to minimize reflectance. Each rack with nine tubes and the appropriate cut-off filters, floated horizontally in both 100-L tanks at a depth of approximately $1 \mathrm{~cm}$ below the surface.

$M$. aeruginosa was exposed to solar irradiances that are normally recorded for temperate latitudes during springtime (October-November). The experimental doses reached were $77.84 \mathrm{~kJ} \mathrm{~m}^{-2}$ of UVBR and $13,295 \mathrm{~kJ} \mathrm{~m}^{-2}$ of total radiation (UVR + PAR) hereafter referred to as "Run 1". The other experiment was done with an UVBR dose of $68.23 \mathrm{~kJ} \mathrm{~m}^{-2}$ and total radiation (UVR + PAR) of $10,285 \mathrm{~kJ} \mathrm{~m}^{-2}$ and will hereafter referred to as "Run 2". Both days of experimentation were contrasting in terms of cloudiness. During Run 1 experiment, the sky remained mostly clear, the average irradiance during the experiment was $0.201 \mathrm{~W} \mathrm{~m}^{-2} \mathrm{~nm}^{-1}$ for $320 \mathrm{~nm}$ and $503 \mathrm{~W} \mathrm{~m}^{-2}$ for PAR. In contrast, during Run 2 experiment the sky remained partially cloudy with an average irradiance during the experiment of $0.179 \mathrm{~W} \mathrm{~m}^{-2} \mathrm{~nm}^{-1}$ for $320 \mathrm{~nm}$ and $478 \mathrm{~W} \mathrm{~m}^{-2}$ for PAR.

Incident solar radiation was monitored continuously during the experiment using a radiometer (model BIC 250, Biospherical Instruments, Inc.), which records irradiances at three wavelengths in the ultraviolet region $(305,320$ and $380 \mathrm{~nm}$, approx. $10 \mathrm{~nm}$ bandwidth). The radiometer was intercalibrated with the reference instrument (RGUV) [61]. Data were recorded every minute at $1 \mathrm{~m}$ of the experimental setup. The equation from Orce and Helbling [62] was used to calculate UVBR doses expressed in $\mathrm{kJ} \mathrm{m}^{-2}$. To monitoring UVAR and PAR irradiances a spectroradiometer (model ILT 950, International Light Technologies, Inc., USA) was used. Data (provided in $\mu \mathrm{W} \mathrm{cm} \mathrm{cm}^{-2}$ ) were recorded every minute next to the BIC 250 radiometer. The spectroradiometer calibration was done by International Light Technologies some weeks before the start of the experiment and inter-calibration was done with GUV 511 from INGEBI.

The effect of solar radiation on the cell abundance of $M$. aeruginosa was evaluated at the end of the exposure treatments ( $4 \mathrm{~h}$ long in average).

The variation (\%) in FAs, TBARS, ROS/RNS, enzymatic antioxidants and cell abundance were calculated as follows:

UVAR $\%=($ TUVA - PAR $) \times 100 /$ PAR.

$\mathrm{UVBR} \%=(\mathrm{TUVR}-\mathrm{TUVA}) \times 100 / \mathrm{PAR}$.

Where PAR, TUVA and TUVB denote the measurements of the respective parameter under each of the irradiance treatments.

\subsection{Sampling and sample analyses}

The short-term incubations started at 9:40 AM until 3:13 PM for the first experiment (Run 1, November 28th 2017) and from 9:48 until 2:18 PM for the second one (Run 2, November 30th 2017) centred approximately at local noon time $(12.30 \mathrm{~h})$.

Culture aliquots for count cells $(1.5 \mathrm{~mL})$ were put into vials, kept in the dark and fixed with formalin that was neutralized with sodium borate. Samples $(8 \mathrm{~mL}$ for all of them except FA with $10 \mathrm{~mL}$ ) for 2-7-dichlorodihydrofluorescein diacetate (DCF-DA) oxidation rate, for in vivo ROS/RNS detection, CAT/SOD/GST, FA, TBARS and Chl-a were filtered through $\mathrm{GF} / \mathrm{F}$ fiber glass filters $(0.7 \mu \mathrm{m})$ and kept at $-80{ }^{\circ} \mathrm{C}$ until analysis except for the immediately analysis of reactive species production.

\subsection{Fatty acids}

After the filtration on GF/F filters, the samples were stored at $-80{ }^{\circ} \mathrm{C}$ before analyses. The method described by Abdulkadir and Tsuchiya [63], modified by De Troch et al. [64] was applied for lipid extraction. FAs methyl esters (FAME) were analyzed using a gas chromatograph (HP $6890 \mathrm{~N}$ ) coupled to a mass spectrometer (HP 5973) according to the procedures described by Hernando et al. [65].

Shorthand FA notations of the form $\mathrm{A}: \mathrm{B} \omega \mathrm{X}$ are used, where $\mathrm{A}$ represents the number of carbon atoms, $\mathrm{B}$ gives the number of double bonds and $\mathrm{X}$ gives the position of the double bond closest to the terminal methyl group [66].

\subsection{DCFH-DA oxidation rate}

The oxidation of $2^{\prime}, 7^{\prime}$-dichlorodihydrofluorescein diacetate (DCFH-DA) was used to determine the reactive species cellular content. Such determination was evaluated in vivo and the quantification is proportional to the oxidation of the 
non-fluorescent 2',7'dichlorodihydrofluorescein $\left(\mathrm{H}_{2} \mathrm{DCF}\right)$ to the highly fluorescent compound $2^{\prime}, 7^{\prime}$ 'dichlorofluorescem (DCF) in presence of ROS/RNS.

According to Bass et al. [67], filters with M. aeruginosa cells were incubated in the dark for $30 \mathrm{~min}$ in $2 \mathrm{~mL}$ of $40 \mathrm{mM}$ Tris- $\mathrm{HCl}$ buffer ( $\mathrm{pH} 7.0$ ), in the presence of $5 \mu \mathrm{M}$ DCFH-DA at $27{ }^{\circ} \mathrm{C}$. Modifications were made to the technique according to Malanga et al. [68]. The fluorescence of the supernatant was determined in a microplate reader (Beckman counter DTX 880, Multimode Detectors) with excitation $\left(\lambda_{\mathrm{ex}}\right)$ at $498 \mathrm{~nm}$ and emission $\left(\lambda_{\mathrm{em}}\right)$ at $525 \mathrm{~nm}$. In all cases, parallel blank controls were included.

\subsection{TBARS}

Cellular TBARS content was used as an indicator of lipid peroxidation. TBARS content provides a rough estimate of the presence of aldehydes, yet most reactivity originates from malondialdehyde (MDA), a product of lipid peroxidation that can react with thiobarbituric acid under acidic and hot conditions to allow a colorimetric assay. Samples for TBARS analyses were filtered through $0.7 \mu \mathrm{m}$ glass-fiber filters, which were stored for less than 2 months at $-80{ }^{\circ} \mathrm{C}$ before analysis. These filters were submerged in $2 \mathrm{ml}$ of both $120 \mathrm{mM}$ potassium chloride and $50 \mathrm{mM}$ potassium phosphate buffer ( $\mathrm{pH} 7.0$ ), sonicated, and centrifuged at $600 \mathrm{~g}$ for $10 \mathrm{~min}$. An aliquot $(0.8 \mathrm{~mL})$ of the supernatant was treated with $0.7 \mathrm{~mL} 30 \%(\mathrm{w} / \mathrm{v})$ Trichloroacetic acid (TCA) and $50 \mathrm{mM}$ potassium phosphate buffer $(\mathrm{pH} 7.0)$, and brought to a final volume of $2 \mathrm{~mL}$ before centrifugation. A volume of $0.2 \mathrm{~mL}$ of $3 \%(\mathrm{w} / \mathrm{v})$ sodium dodecyl sulfate (SDS) and $0.05 \mathrm{~mL}$ of $4 \%(\mathrm{w} / \mathrm{v})$ butylatedhydroxytoluene (BHT) in ethanol were added to $1 \mathrm{~mL}$ of the supernatant from the second centrifugation. After mixing, $2 \mathrm{~mL}$ of $0.1 \mathrm{~N} \mathrm{HCl}, 0.3 \mathrm{~mL}$ of $10 \%(\mathrm{w} / \mathrm{v})$ phosphotungstic acid and $1 \mathrm{~mL}$ of $0.7 \%(\mathrm{w} / \mathrm{v})$ 2-thiobarbituric acid were added. The mixture was heated at $95{ }^{\circ} \mathrm{C}$ in a water bath for $45 \mathrm{~min} .5 \mathrm{~mL}$ of $n$-butanol were added before the sample was vortexed, and centrifuged at $600 \mathrm{~g}$ for $10 \mathrm{~min}$. The fluorescence of the supernatant organic layer was measured at $\lambda_{\mathrm{ex}}=15 \mathrm{~nm}$ and $\lambda_{\mathrm{em}}=555 \mathrm{~nm}$. The values were expressed as nmol TBARS (malondialdehyde equivalents) per particulate carbon units. Malondialdehyde standards were prepared from 1,1,3,3-tetramethoxypropane [69].

\subsection{CAT, SOD and GST activity}

CAT activity was evaluated by the decomposition rate of hydrogen peroxide $\left(\mathrm{H}_{2} \mathrm{O}_{2}\right)$ at $240 \mathrm{~nm}$ at $25^{\circ} \mathrm{C}$ as described by Beutler [70], using a phosphate buffered saline tablet (C987D49, Sigma-Aldrich Inc., USA). One unit of CAT was defined as the amount of enzyme catalyzing the elimination of $1 \mu \mathrm{M} \mathrm{H}_{2} \mathrm{O}_{2}$ per minute.
For the SOD and GST activity, cell extracts were obtained using the same process as that used for the CAT assay. The SOD activity was measured using a SOD assay kit (Cayman Chemicals). The amount of enzyme to exhibit $50 \%$ of dismutation of the superoxide radical correspond to one unit [71].

The activity of GST was assayed by the method of Habig et al. [72]. The reaction mixture $(200 \mu \mathrm{L})$ consisted of $50 \mathrm{mM}$ potassium phosphate buffer (pH 7.0), $200 \mathrm{mM} \mathrm{GSH}$, $100 \mathrm{Mm}$ 1-chloro-2,4-dinitrobenzene (CDNB) and an aliquot of sample to be tested. The enzyme activity was calculated using a molar extinction coefficient of 2,4-dinitrophenyl-S-glutathione as $9.6 \mathrm{nM}^{-1} \mathrm{~cm}^{-1}$ at $340 \mathrm{~nm}$ and $25^{\circ} \mathrm{C}$. One unit of GST was defined as the amount of enzyme catalyzing the formation of $1 \mu \mathrm{mol}$ of 2,4 dinitrophenyl-Sglutathione per min.

\subsection{Cell counts}

To quantify cell abundance, the procedure determined by Legresley and McDermott [73] was followed using a Sedwick-Rafter counting chamber with under a phase contrast Olympus inverted microscope. Samples were first sonicated with an ultrasonic homogenizer (US50; Nissei Co., Tokio, Japan) to separate the colonies into single cells.

\subsection{Statistical analyses}

One-factor ANOVA was performed (Statistica, version 9) to determine the significance of the differences observed between treatments for each parameter values at different solar irradiances/temperatures. A Tukey post hoc test was additionally performed to determine the differences between treatments [74].

Changes in the relative amounts of unsaturated FAs in relation to irradiance treatment/temperature was further evaluated by one-way ANOVA analyses based on the concentration ratio of UFAs/saturated FAs (UFAs/SFAs). The FAs used to calculate a UFAs/SFA ratio were those that contributed $>15 \%$ to the total FA concentration. The SFAs used for calculation of the UFAs/SFAs ratio were 16:0 plus 18:0 considering that both of them showed the higher concentrations as compared to the other saturated FA found (12:0, iso-15:0, 14:0, 15:0, iso-16:0 and 17:0).

\section{Results}

\subsection{Impact of temperature and UVR on FA profiles}

A decrease in the UFAs/SFA ratio of $11 \%$ was observed under UVAR at $26{ }^{\circ} \mathrm{C}$ for the experimental high solar irradiance (Run 1) (Table 1). Under an increased temperature, this UVAR decrease as of $44 \%$ compared to the ratio 


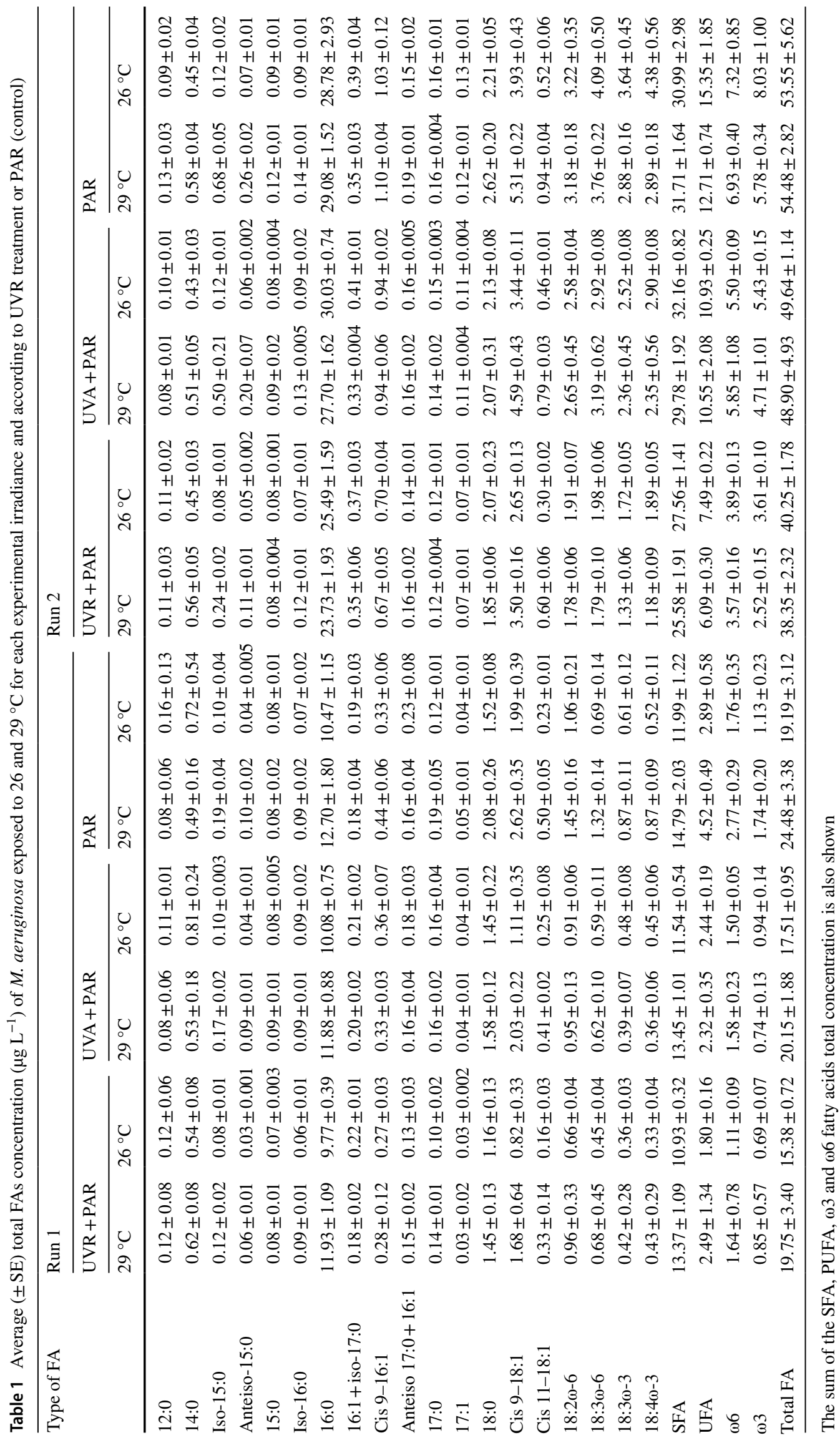


Fig. 1 Quotient UFAs (sum of all of them) over the SFAs $(16: 0+18: 0)$ (relative abundance) as a function of high or low solar irradiances when exposed cultures at $26^{\circ} \mathrm{C}$ (white bars) and $29^{\circ} \mathrm{C}$ (black bars). Each bar represents the mean relative abundance $\pm \mathrm{SE}$ Different letters correspond to significant differences (Tukey test) between treatments inducing a percentage of change ("-" refers to relative decrease) by UVBR or UVAR in relation to PAR considered as $100 \%$ of the value for each parameter

Fig. 2 Quotient between the main PUFAs (A) 18:2 $\omega 6,(\mathbf{B})$ 18:3 $\omega 6$ and (C) 18:1-cis9 over SFAs $(16.0+18.0)$ (relative abundance) as a function of high or low solar irradiance when exposed cultures at $26{ }^{\circ} \mathrm{C}$ (white bars) and $29^{\circ} \mathrm{C}$ (black bars). Each bar represents the mean relative abundance $\pm \mathrm{SE}$ Different letters correspond to significant differences (Tukey test) between treatments inducing a percentage of change ("-" refers to relative decrease) by UVBR or UVAR in relation to PAR considered as $100 \%$ of the value for each parameter

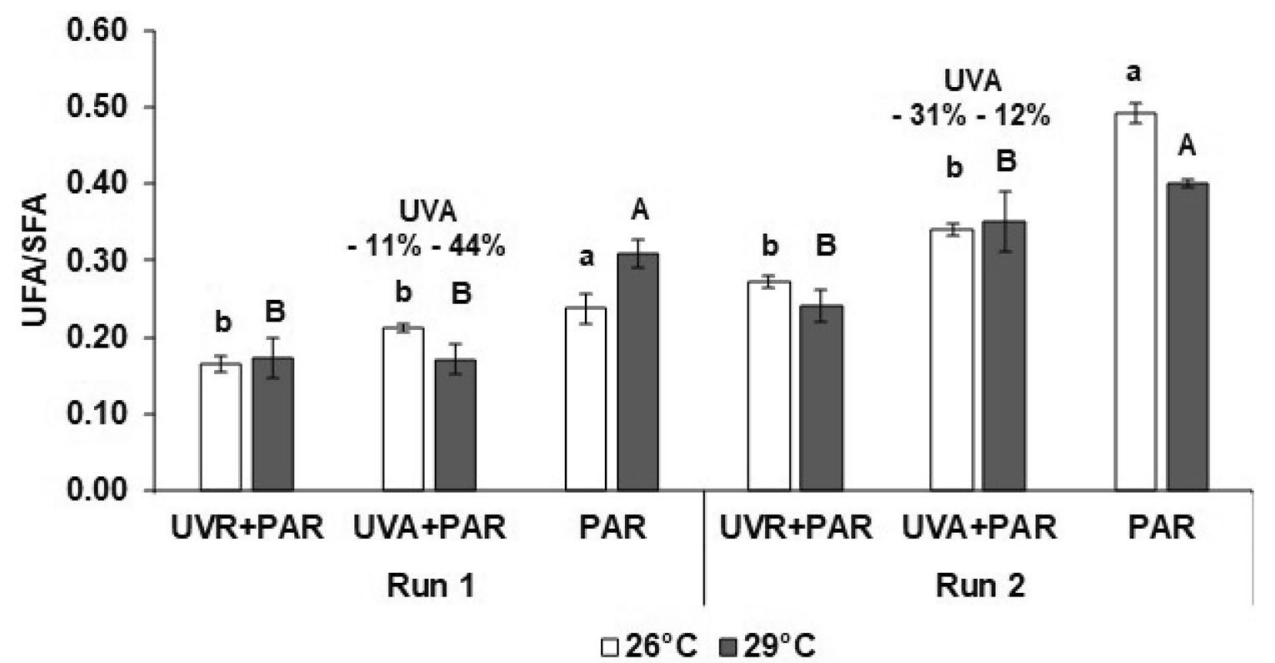

A

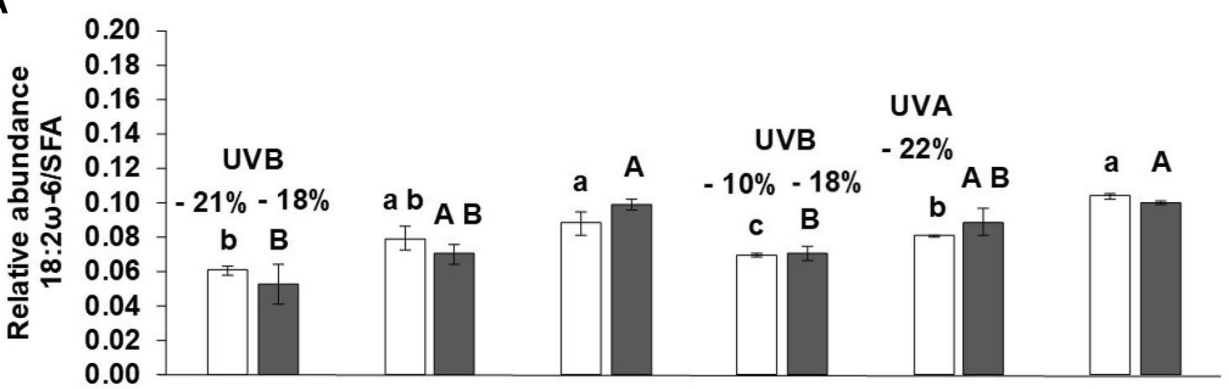

B

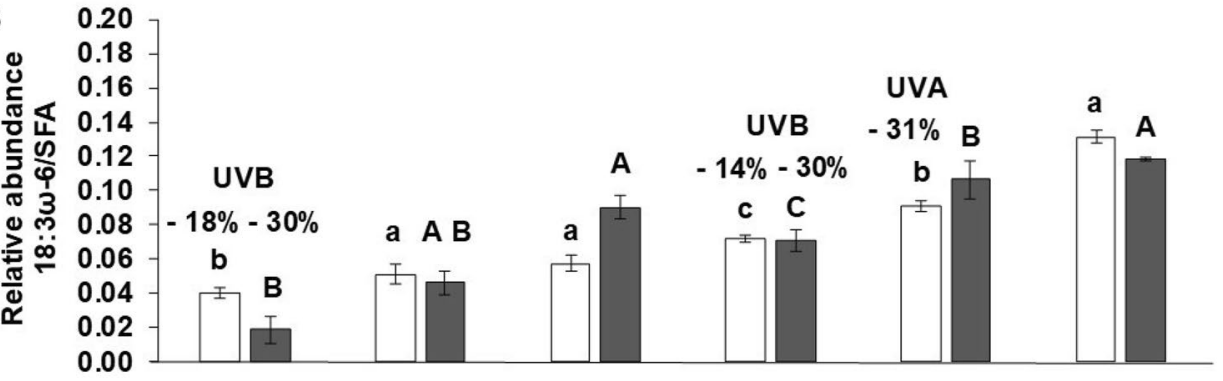

C

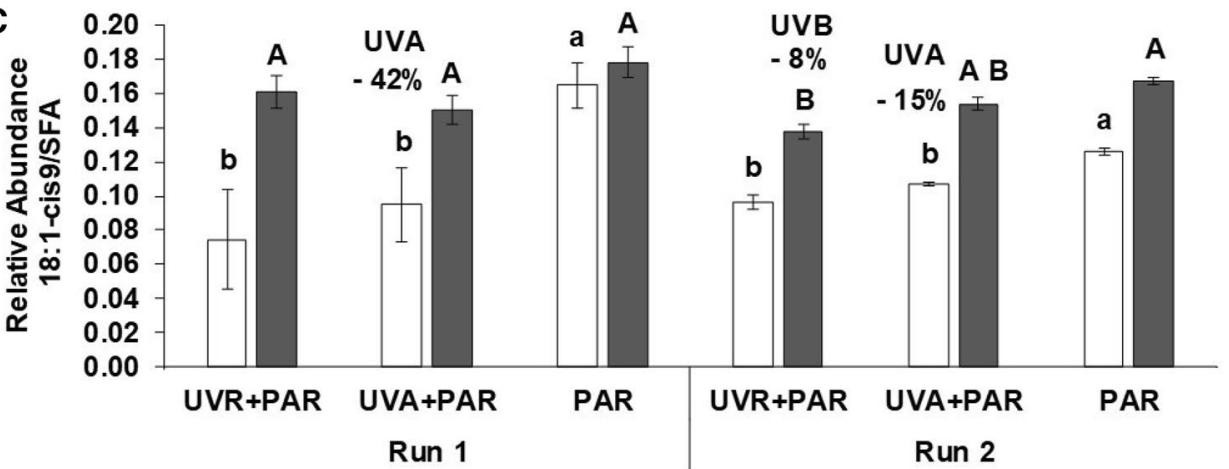

$\square 26^{\circ} \mathrm{C} \square 29^{\circ} \mathrm{C}$ 
Fig. 3 Quotient between of the main PUFAs (A) 18:303

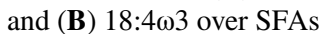
$(16.0+18.0)$ (relative abundance) as a function of high or low solar irradiance when cultures were exposed at $26^{\circ} \mathrm{C}$ (white bars) and $29^{\circ} \mathrm{C}$ (black bars). Each bar represents the mean \pm SE Different letters correspond to significant differences (Tukey test) between treatments inducing a percentage of change ("-" refers to relative decrease) by UVBR or UVAR in relation to PAR considered as $100 \%$ of the value for each parameter

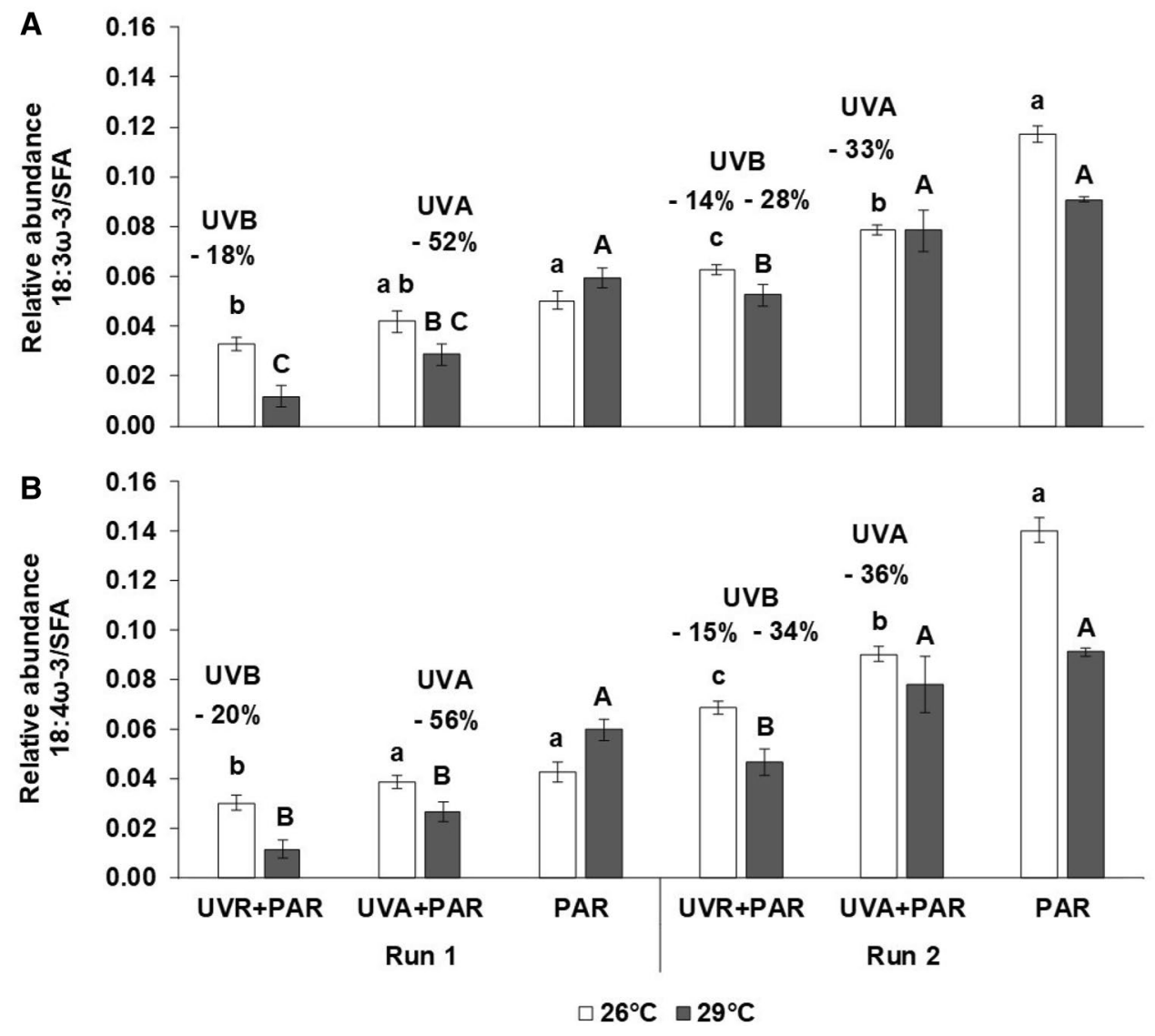

values without UVR radiation. No decrease by UVBR was observed at this high irradiance (Run 1). However, for a low irradiance (Run 2), it was produced a ratio decrease of $12 \%$ on cultures exposed at $29{ }^{\circ} \mathrm{C}$ and $31 \%$ due to UVAR at $26^{\circ} \mathrm{C}$ (Fig. 1).

Changes in the relative abundance of PUFAs were evident in the different UVR treatments (Fig. 2, 3). The high solar irradiance (Run 1) produced a significant decrease (21\%) of the ratio $18: 2 \omega 6 / \mathrm{SFA}$ at $26^{\circ} \mathrm{C}$ by UVBR while this was not the case for cultures exposed to only UVAR comparing with the PAR treatment. At $29^{\circ} \mathrm{C}$, the UVBR decreased the ratio $18: 2 \omega 6 /$ SFA to $18 \%$. Whereas with a low solar irradiance (Run 2) the decreased ratio was observed in both UVBR $(10 \%)$ and UVAR $(22 \%)$ exposure at $26^{\circ} \mathrm{C}$. At $29^{\circ} \mathrm{C}$, the ratio 18:2 $\omega 6 /$ SFA decreased only as consequence of UVBR exposure (18\%) (Fig. 2A).

The ratio 18:3 $\omega 6 /$ SFA changed in a similar way compared to $18: 2 \omega 6$ but with a high percentage of decrease for both UVBR and UVAR. Thus, the ratio decreased with $18 \%$ at $26{ }^{\circ} \mathrm{C}$ and $30 \%$ at $29{ }^{\circ} \mathrm{C}$ for UVBR when the irradiance was high (Run 1). The UVAR did not generate any effect in any temperature treatment. Simultaneously, cultures exposed to a low irradiance (Run 2) at $26{ }^{\circ} \mathrm{C}$ showed a decrease in the ratio by UVB (14\%) due to significant differences between TUVR and TUVA treatments $(P<0.01)$, as well as by exposure to UVAR (31\%) due to significant differences between TUVA and PAR treatments $(P<0.01)$. At $29^{\circ} \mathrm{C}$, the $18: 3 \omega 6 /$ SFA ratio was significantly lower only for UVBR exposure (30\%) but not by UVAR considering that there were no significant differences between TUVA and PAR $(P>0.05)$ (Fig. 2B).

The 18:1-cis9/SFA ratio showed a significant decrease of $42 \%$ and $15 \%$ for high (Run 1) and low (Run 2) irradiance of UVAR at $26{ }^{\circ} \mathrm{C}$, respectively. For a high irradiance, no significant decrease due to UVR was observed in cells at 29 or $26^{\circ} \mathrm{C}$. Meanwhile, for a low irradiance (Run 2) there was a significant decrease of the ratio due to UVBR (8\%) at high temperature (Fig. 2C).

The ratio of both $\omega 3$ PUFAs to SFA changed similarly with a decrease of $18 \%$ and $20 \%$ for $18: 3 \omega 3$ and $18: 4 \omega 3$, respectively due to a UVBR exposed to a high irradiance (Run 1) at $26^{\circ} \mathrm{C}$ and no decrease was observed at the UVAR exposure (Fig. 3A, B). Opposite to these results, at $29^{\circ} \mathrm{C}$, no decreased ratio values were observed at exposure to UVBR, however values decreased because of UVAR (52 and $56 \%$ for $18: 3 \omega 3$ and $18: 4 \omega 3$, respectively). When UVBR irradiance was low (Run 2) at $26{ }^{\circ} \mathrm{C}$ there was a decreased ratio by exposure to UVBR (14 and $15 \%$ for $18: 3 \omega 3$ and $18: 4 \omega 3$, respectively) as well as for UVAR ( 33 and $36 \%$ for

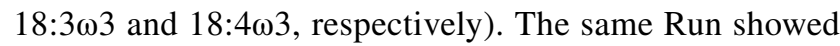


no ratio changes at $29^{\circ} \mathrm{C}$ by UVAR exposure considering that TUVA and PAR treatments were not significantly different $(P>0.05)$. However, the ratio decreased after the

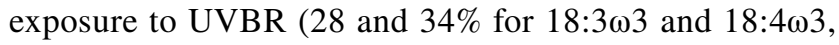
respectively) (Fig. 3A,B). When the ratio between $\omega 6$ and $\omega 3$ FAs was evaluated, we determined a significant increase due to UVAR of $13 \%$ and $34 \%$ when cultures were incubated at 26 and $29{ }^{\circ} \mathrm{C}$, respectively, at a high irradiance (Run 1). With the exposure to a low irradiance (Run 2), the UVAR produced an increased ratio of $11 \%$ at $26^{\circ} \mathrm{C}$. In addition, the UVBR produced an increase of 7 and $15 \%$ when cultures were exposure at 26 and $29^{\circ} \mathrm{C}$, respectively (Table 1 , Fig. 4).

\subsection{Oxidative metabolism}

The initial reactive species concentration was not significantly different between both temperatures although the values were higher in Run 2 compared to Run 1. For the experimental high irradiance (Run 1 ) at $26{ }^{\circ} \mathrm{C}$, there were no differences in cellular ROS/RNS concentration between the TUVA and PAR treatments $(P>0.05)$. However, there were significant differences between TUVR and PAR treatments $(P<0.01)$. These increments, as consequence of exposure to UVBR, reached a maximum of $503 \%$ on average. For cells exposed to $29{ }^{\circ} \mathrm{C}$, no significant differences were found between any treatment
Fig. $4 \omega 3 / \omega 6$ FAs ratio as a function of high or low solar irradiance when exposed cultures at $26^{\circ} \mathrm{C}$ (white bars) and $29^{\circ} \mathrm{C}$ (black bars). Each bar represents the mean $\pm \mathrm{SE}$ Different letters correspond to significant differences (Tukey test) between treatments inducing a percentage of change ("+" refers to relative increase) by UVBR or UVAR in relation to PAR considered as $100 \%$ of the value for each parameter

Fig. 5 Oxidative stress parameters in $M$. aeruginosa cultures exposed to $26^{\circ} \mathrm{C}$ (white bars) and $29^{\circ} \mathrm{C}$ (black bars) and UVR treatment as a function of high or low solar irradiances. (A) DCF-DA oxidation rate, (B) lipid peroxidation (TBARS cell content). Each bar represents the mean \pm standard error (SE). Different letters correspond to significant differences (Tukey test) between treatments inducing a percentage of change (" +" refers to relative increase) by UVBR or UVAR in relation to PAR considered as $100 \%$ of the value for each parameter. Initial time refers to cell values at the beginning of each experiment of exposure to sunlight
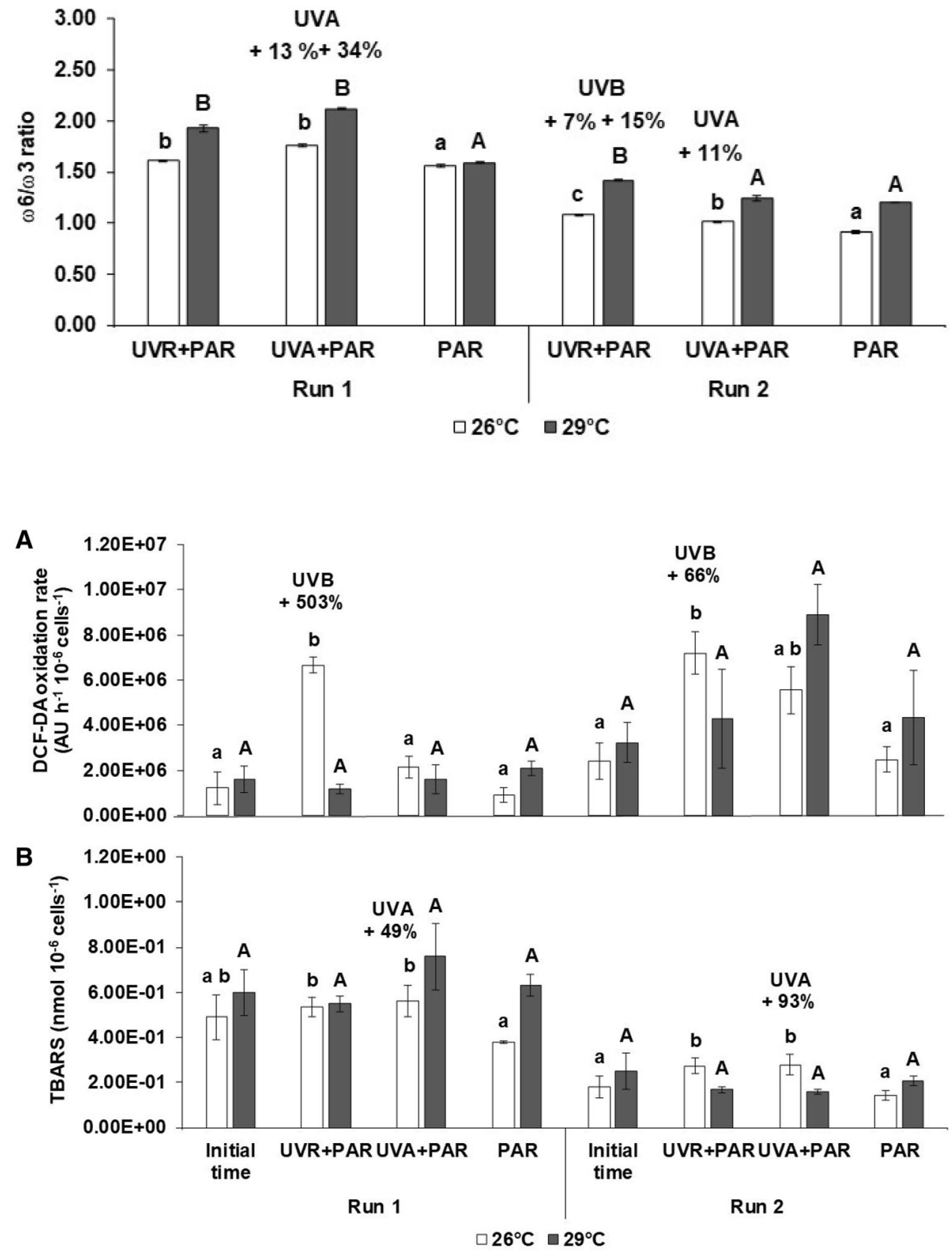
$(P>0.05)$. With the exposure to the low irradiance (Run 2) at $26{ }^{\circ} \mathrm{C}$, a similar trend was observed to the one observed for the high irradiance (Run 1) at $26{ }^{\circ} \mathrm{C}$, although with this irradiance, the increase in ROS/RNS concentration due to exposure to UVBR reached only $66 \%$. No significant differences were observed between any treatment $(P>0.05)$ when exposing the cells at $29^{\circ} \mathrm{C}$ (Fig. 5A).

In the initial time, the TBARS values were not significantly different between temperatures in both experiments. The TBARS content was significantly higher in TUVA (49\%) compared to the PAR treatment $(P<0.01)$ but no significant differences were found for the TUVR $(P>0.05)$ at $26{ }^{\circ} \mathrm{C}$ and the UVBR high irradiance (Run 1). A high increased lipid damage by UVAR (93\%) was also observed in the low exposure irradiance (Run 2) (Fig. 5B).

\subsection{Antioxidant protection}

At the initial time, no differences in CAT activity were found between temperatures in both experiments. However, for SOD and GST the activity was significantly higher at $29^{\circ} \mathrm{C}$ compared to $26^{\circ} \mathrm{C}$ for both experiments. The CAT activity was significantly reduced only due to exposure to UVBR (18\%) at $26^{\circ} \mathrm{C}$ with a high irradiance (Run 1). Meanwhile, at an incubation temperature of $29^{\circ} \mathrm{C}$, no significant differences in CAT activity were found between TUVR and PAR $(P>0.05)$, however a significantly increased activity due the exposure to UVAR $(132 \%)$ was observed. In a low irradiance (Run 2) no significant differences between treatments was observed $(P>0.05)$ at $26{ }^{\circ} \mathrm{C}$ but an increased CAT due to UVAR (93\%) was determined at $29^{\circ} \mathrm{C}$ in coincidence with high irradiance (Fig. 6A).

SOD activity significantly increased due to both UVBR $(172 \%)$ and UVAR $(133 \%)$ at $26^{\circ} \mathrm{C}$ with the high irradiance
Fig. 6 Antioxidants activity A CAT, B SOD and C GST as a function of high or low solar irradiance when cultures were exposed at $26^{\circ} \mathrm{C}$ (white bars) and $29^{\circ} \mathrm{C}$ (black bars). Each bar represents the mean antioxidant activity \pm SE Different letters correspond to significant differences (Tukey test) between treatments inducing a percentage of change (" + and -" refers to relative increase or decrease respectively) by UVBR or UVAR in relation to PAR considered as $100 \%$ of the value for each parameter. Initial time refers to cell values at the beginning of each experiment of exposure to sunlight
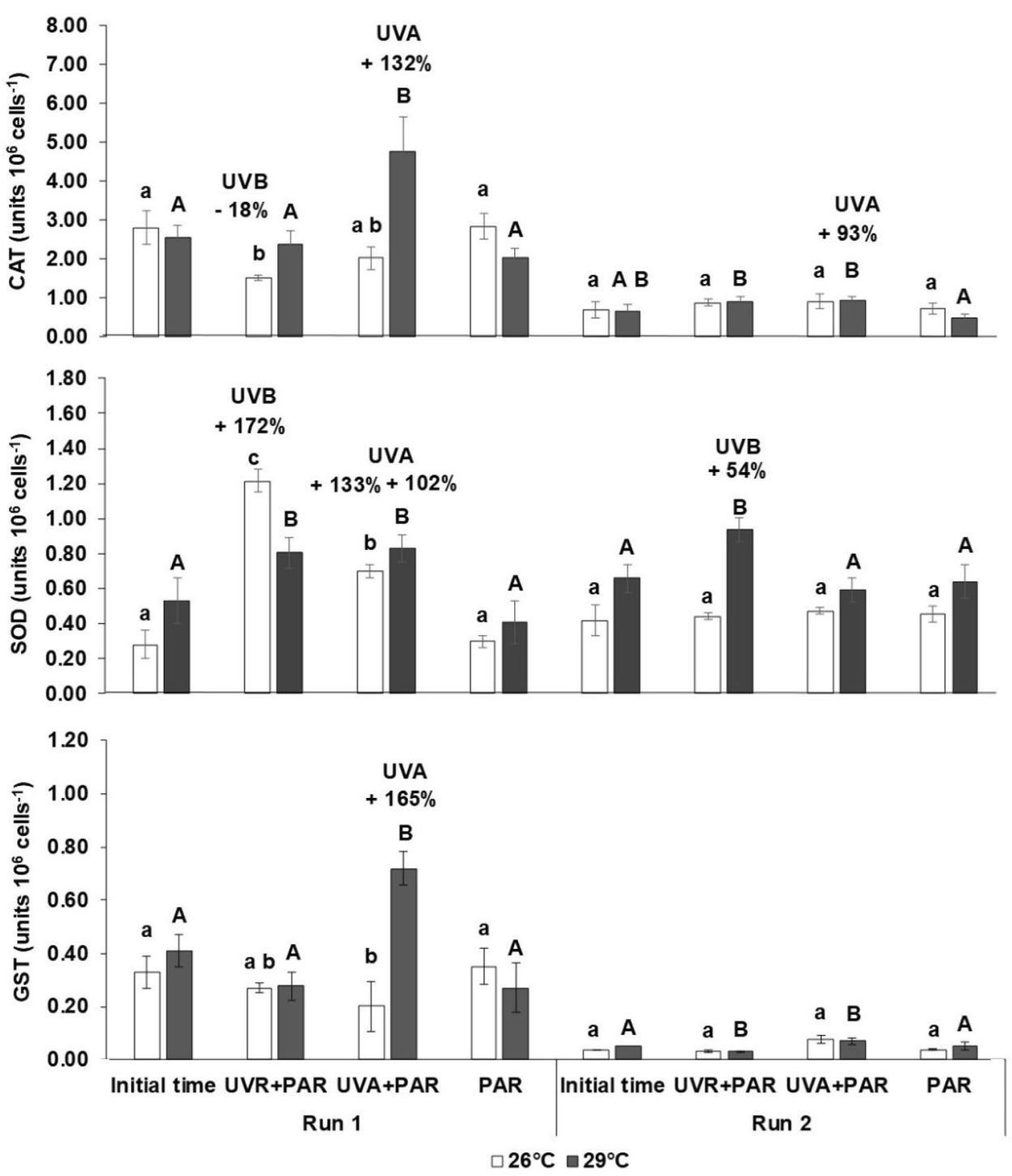
(Run 1). At $29{ }^{\circ} \mathrm{C}$, there was a significantly increased SOD activity due only to UVAR (102\%). While at the low irradiance (Run 2), no significant differences were found between treatments at $26{ }^{\circ} \mathrm{C}$ but an increased activity was observed due to UVAR (54\%) at $29^{\circ} \mathrm{C}$ (Fig. 6B).

GST activity was the same for all treatments $(P>0.05)$ at $26{ }^{\circ} \mathrm{C}$ for the high irradiance (Run 1). At $29^{\circ} \mathrm{C}$, there was an increased activity due to UVAR (165\%) with respect to the PAR treatment. At the low irradiance (Run 2), no significant differences were registered at any temperature $(P>0.05)$ (Fig. 6C).

\subsection{Impact of temperature and UVR on cell abundance}

The initial cell abundance was not significantly different between temperatures; however, the values were higher in Run 2 (in average $4.610^{9}$ cell $\mathrm{L}^{-1}$ ) compared to Run 1 (in average $2.110^{9}$ cell $\mathrm{L}^{-1}$ ). No significant differences were found between such initial values and PAR values after UVR treatments at any temperature but there was a decrease of around $10 \%$ and 5\% for Run 1 and 2, respectively (Fig. 7). For the high experimental UVBR irradiance (Run 1) at $26{ }^{\circ} \mathrm{C}$, there were a significant decrease in cell abundance due to UVBR (18\%) and for UVAR (20\%) considering the significant differences $(P<0.01)$ between TUVR and PAR as well as between TUVA and PAR, respectively. However, when cells were exposed to the same irradiance but in a batch temperature of $29^{\circ} \mathrm{C}$, no significant differences between TUVR and TUVA $(P>0.05)$ were found, despite the significant differences of both treatments with PAR. These results indicate a cell abundance inhibition (reduced by $20 \%$ ) only due to UVAR (Fig. 7).
For low experimental irradiance (Run 2) at 26 and $29^{\circ} \mathrm{C}$, there were a significant decrease in cell abundance only for UVAR (17 and 13\%, respectively), considering that any differences were found between cell numbers in TUVR compared with TUVA treatment. The cell number in the PAR treatment was significantly higher $(P<0.01)$ compared with the other two treatments (Fig. 7).

\section{Discussion}

M. aeruginosa is one of the major bloom-forming cyanobacterial species, which forms noxious blooms in La Plata River basin every year, causing negative impacts on the ecosystem and human health. It is, therefore, important to assess the manner in which these cyanobacteria may adapt to climate change. The experimental conditions of this study simulate their response to high temperatures and then an exposure to high (Run 1) or low (Run 2) solar irradiance depending on the cloudiness of the sky and with different cells abundance as normally occurs.

The cell abundance in Run 2 reached around $4 \times 10^{9} \mathrm{~L}^{-1}$ cells, doubling the abundance of Run 1 as usually occurs over time in the La Plata basin blooms. It can produce selfshading [75-77]. Thus, lower irradiance in Run 2 and high abundance were also considered for the interpretation of our results.

\subsection{Impact of temperature and UVR on FA profiles}

Previous studies have shown that UVR can affect FAs in cyanobacteria by damaging cell integrity including oxidative damage over unsaturated or polyunsaturated lipids [78]. He

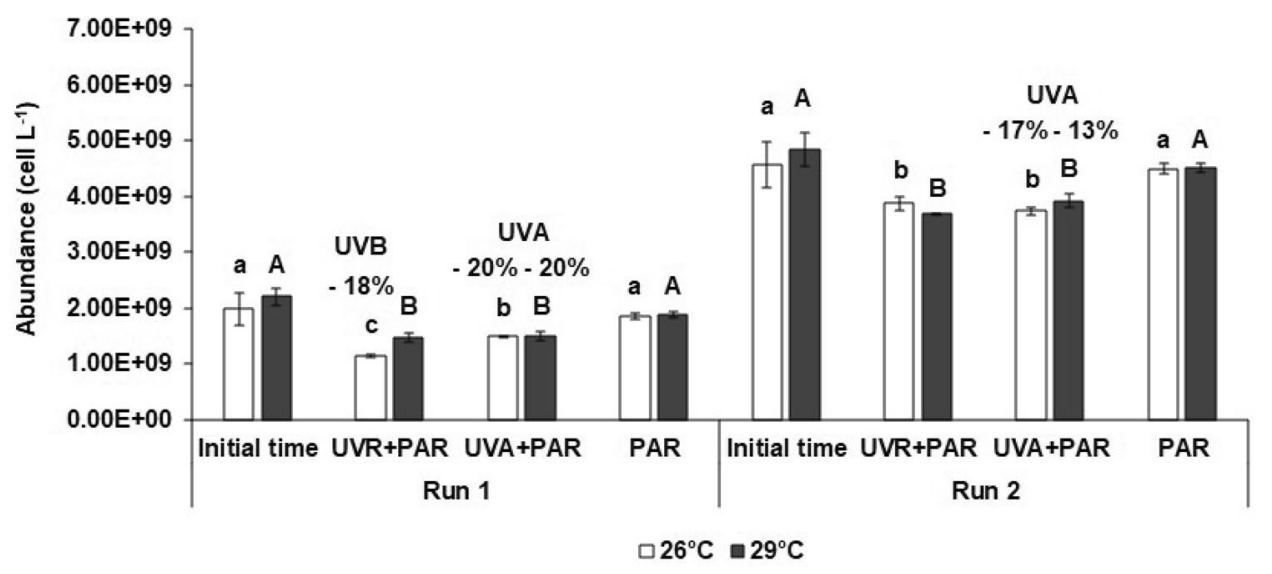

Fig. 7 M. aeruginosa abundance (cell $\mathrm{L}^{-1}$ ) as a function of high or low solar irradiance when cultures were exposed at $26{ }^{\circ} \mathrm{C}$ (white bars) and $29{ }^{\circ} \mathrm{C}$ (black bars). Each bar represents the average abundance $( \pm \mathrm{SE})$. Different letters correspond to significant differences (Tukey test) between treatments inducing a percentage of change

("-" refers to relative decrease) by UVBR or UVAR in relation to PAR treatment considered as $100 \%$ of the value for each parameter. Initial time means cell values at the beginning of each experiment of exposure to sunlight 
and Häder [27] have shown PUFA peroxidation in the cyanobacteria Anabaena sp. due to UVBR exposure. In addition, Zeeshan and Prasad [79] demonstrated differential response of growth, photosynthesis, antioxidant enzymes and lipid peroxidation to UVBR in three cyanobacteria species (Nostoc muscorum, Plectonema boryanum, and Aphanothece sp.). When the change in the general composition of FAs was evaluated by the UFA/SFA ratio (relative abundance), a decrease in UFA (with a $>10 \%$ threshold in the total FAs concentration) was determined due to UVAR, mainly at $26^{\circ} \mathrm{C}$ for both irradiance Runs, independently of cell abundance and coinciding with the lipid damage (TBARS). In coincidence, Chris et al. [80] found an increased lipid damage in Cylindrospermum sp. exposured to UVBR and by exposure to UVBR an increase in TBARS was determined for $P$. corium [81]. This increase in lipid damage, with a MDA increase, is the result of oxidative damage of PUFA in the cell membranes [82]. In other cyanobacteria, the UVR exposure damaged the SFA [83]. Thus, the SFA composition of Spirulina platensis after UVBR decreased $50 \%$ while PUFA increased 25\%. Bhandari and Sharma [81] reported a SFA decrease after UVBR exposure in $N$. spongiaeforme. In our study, an evident decrease of UFA was found mainly as consequence of UVAR exposure. The lipid damage observed at $26{ }^{\circ} \mathrm{C}$ under high irradiance was only registered by a decreased in ratio 18:1-cis9/SFA. However, with high temperature, the PUFA evaluated decreased as consequences of UVAR (in coincidence with TBARS increased, see above). Despite these results, at $29^{\circ} \mathrm{C}$ the UVAR decreased the $\omega 3$ PUFA with about $50 \%$ for high irradiance but with no effects at low irradiance plus self-shading. Clearly the $\omega 3$ FA were highly sensitive to high UVAR irradiance at both exposure temperatures. Regarding the UVBR effects, $\omega 3$ and $\omega 6$ FA were highly sensitive at $26^{\circ} \mathrm{C}$ independently of irradiance level or cell abundance. These results showed insufficient protection by antioxidant activity/consumption and some damage probably caused by $\mathrm{H}_{2} \mathrm{O}_{2}$ production [44]. However, the $\omega 3$ were not affected by UVBR in high irradiance conditions at $29^{\circ} \mathrm{C}$ with a lower SOD activity compared with $26{ }^{\circ} \mathrm{C}$ but with a similar CAT activity compared with the PAR treatment. Babele et al. [37] reported an increased enzymatic antioxidant level due to UVBR and temperature increase exposure with a protective role avoiding lipid damage. This is also evident from the present findings as it was noted that the exposure of cultures to high UVBR irradiance at $26{ }^{\circ} \mathrm{C}$ (plus previous exposure period at such temperature) resulted in a significant increase in the SOD activity. It was previously reported for Anabaena sp [84] and also for $M$. aeruginosa [37]. Interestingly when cells were exposed to UVAR at $29^{\circ} \mathrm{C}$, the increased activity of SOD, CAT and GST was not enough to avoid UFA damage (see below). As previously mentioned, the energy level of UVAR is very high in high solar irradiance. However, when solar irradiance was low and plus high cell abundance, no UFA damage was observed in $\omega 3$ or $\omega 6$ FA or 18:1-cis9 with a CAT activity increased in UVAR at $29^{\circ} \mathrm{C}$ (see below).

It has been shown that under stress conditions, the fluidity of the plasma membrane can be regulated through changes in the composition of UFAs, thus modifying the physiological response [84]. In addition, it is known that an increase in membrane lipid unsaturation increases the tolerance of cyanobacteria to UVR $[85,86]$. PUFAs are very important components in the membrane-chlorophyll complex in cyanobacteria $[87,88]$. Thus, our results suggest that the high antioxidant protection of UFA due to temperature increase supported the resistance of Microcystis to the UVR effects [83]. Another possible adaptation mechanism for an increased membrane lipid unsaturation is the protection of these enzymes from inactivation at high UVBR [89]. It was proved to be a covalent modification with membrane lipids associated proteins [90]. No inhibition was observed by UVAR in high irradiance in any $\omega 6$ FAs at 26 or $29^{\circ} \mathrm{C}$, although the relative abundance of both $\omega 6$ has decreased with a low irradiance plus self-shading between 22 and $31 \%$ only in at $26{ }^{\circ} \mathrm{C}$. However, increasing the exposure temperature does not show any decrease in $\omega 6$ FAs relative abundance probably due to an increased CAT and GST activity (see below).

To determine if there is a differential sensitivity of the different FAs to RUV, the ratio $\omega 6 / \omega 3$ FA was analyzed. Thus, the concentration of $\omega 6$ was significantly higher at both temperatures due to exposure to high UVAR irradiance and doubling the concentration under conditions of high temperature with greater antioxidant activity (see below). In exposure to a lower irradiance plus self-shading, the increase of $\omega 6$ FAs was due to UVAR and UVBR. With these results we can demonstrate a higher UVR sensitivity of $\omega 3$ FAs.

\subsection{Enzymatic protection by temperature and UVR effects}

Clear differences were found between the initial values of reactive species when comparing high with low irradiance, being higher in Run 2, probably due to the high cell abundance. Although the cultures exposed to low irradiance continued to grow exponentially, the increase in cell abundance was around $100 \%$ because Run 2 experiment was carried out 2 days after the experiment with high irradiance and pre-exposed cultures continued to grow. The consequent low nutrient concentration and an increase in biomass could produce an increase in the reactive species concentration at the beginning of Run 2. Diverse stress factors such as temperature, excessive light forces and nutritional constraint can generate reactive species [91]. Despite the higher reactive species concentration at the start of the incubation, no significant differences were observed in relation to PAR after the 
incubation period, with the exception of the cells exposed to UVBR at $26^{\circ} \mathrm{C}$. However, this difference was about five times larger in the high than in the low irradiance experiment with the consequences that will be explained below. Reactive oxygen species are mainly produced by photosystem I; however, under certain circumstances, PSII contributes to the overall formation of ROS in the thylakoid membrane [49]. The initial basal level of reactive species in the PAR treatment of both experiments can also be explained by the fact that the cells were adapted to a lower PAR level in our culture chamber and despite the pre-adaptation to solar PAR irradiance, it resulted in additional reactive species generation. Previously, it was argued that greater lipid damage by UVAR diminishes or disappears with increasing exposure temperature in response to a greater antioxidant activity. Thus, both SOD and GST have significantly increased their activity due to UVAR exposure at $29^{\circ} \mathrm{C}$. At the initial time of both experiments, these two enzymes already had high concentrations as consequences of pre-adaptation at $29^{\circ} \mathrm{C}$ and continued high during the day of pre-adaptation to solar PAR irradiance. Despite that, their activity was significantly higher at the initial time, after $4 \mathrm{~h}$ of UVAR exposure these cells doubled their SOD activity or even tripled it for GST under high irradiance conditions at $29^{\circ} \mathrm{C}$.

After the UVBR exposure, SOD activity in M. aeruginosa was increased by about $172 \%$ when exposed to high solar irradiance at $26{ }^{\circ} \mathrm{C}$. Such increase in SOD activity could be enough to avoid damage to both $\omega 6$ FAs. Castenholz and Garcia-Pichel [92] registered increased peroxide radical anions in cyanobacteria with high light intensity and the consequent increased synthesis of SOD. Furthermore, Latifi et al. [49] demonstrated that $\mathrm{H}_{2} \mathrm{O}_{2}$, a product of SOD activity, has detrimental effects on cyanobacteria. Previous studies reported that SOD activity in plants can increase or diminish according to the species, UVBR dose and the presence or not of concomitant PAR or UVAR [93].

As was previously mentioned, CAT is an enzymatic antioxidant, which exclusively dismutate $\mathrm{H}_{2} \mathrm{O}_{2}$. It also doubled its activity cells in both solar irradiance, independently of cell abundance when exposed to $29^{\circ} \mathrm{C}$, despite the fact that at the initial incubation time the CAT concentration was the same in cultures grown at 26 or $29{ }^{\circ} \mathrm{C}$ and without significant differences with PAR values after the exposure to Run 1 and 2. Furthermore, CAT activity had a significant decrease at $26{ }^{\circ} \mathrm{C}$ when cells were exposed at high UVBR irradiance. This result has been reported before [41, 94] and inactivation of CAT due to UVBR is a consequence of photo inactivation and degradation [95] of the haem group in CAT. A high reactive species concentration (statistically not significant) was produced in cells exposed to UVAR at $26{ }^{\circ} \mathrm{C}$ with a high solar irradiance, with consequent increased lipid damage despite of an increased SOD activity. For cells exposed at $29^{\circ} \mathrm{C}$ and high UVBR irradiance, no lipid damage was registered probably due to a significant higher CAT (132\%), SOD (102\%) and GST (165\%) activity. An increased temperature may increase the activity of enzymatic antioxidants as was previously mentioned.

In UVBR exposure, the significant increase in reactive species did not impact the general lipid damage index (TBARS), probably due to a significant increase in CAT and SOD at $26{ }^{\circ} \mathrm{C}$. This protection has been more effective for $\omega 3$ compared to the decrease in relative abundance of $\omega 6$. Unlike the effect produced by the increase in temperature on enzymatic antioxidants when exposed to UVAR, no changes in the levels of antioxidants were observed when exposed to UVBR due to temperature increases in high solar irradiance. The increase in enzymatic antioxidant activity noted at $29{ }^{\circ} \mathrm{C}$ was not present in exposure to UVBR in high or low irradiance, probably due to the lack of an increase in the concentration of reactive species due to the previous adaptation to $29^{\circ} \mathrm{C}$. Instead, by exposing the cells to UVAR, the high SOD and GST activity by previous exposure to $29^{\circ} \mathrm{C}$ and the increase of CAT, SOD and GST during the exposure to high irradiance, avoided an increase in the reactive species concentration and the consequent lipid damage. The decrease in CAT activity after UVBR exposure to high irradiance was probably due to enzymatic damage at high UVBR dose as previously explained. However, an increase in SOD was observed by UVBR exposure at $29^{\circ} \mathrm{C}$ when the cultures were exposed to a low solar irradiance plus high cell abundance.

\subsection{Impact of temperature and UVR on cell abundance}

Decreases in abundance and growth under UVBR have been reported in several cyanobacterial strains such as Anabaena sp. [27], M. aeruginosa [37, 44]. However, in our experimental conditions, we found some differences between temperature incubations. Thus, at $26{ }^{\circ} \mathrm{C}$ and higher experimental solar irradiance, we found a decreased cell abundance by exposure to UVBR and UVAR. When the incubations temperature was $29^{\circ} \mathrm{C}$ at high irradiance, only the UVAR produced a decrease in cell abundance. According to our results, such UVBR protection cannot be explained by an increase in CAT, SOD or GST activity. Probably the absence of an increase in the concentration of reactive species and cell protection at $29{ }^{\circ} \mathrm{C}$ may be due to a high consumption of non-enzymatic antioxidants under high temperature conditions (not determined). Regarding to UVAR, as previously demonstrated, some antioxidants protections are induced as consequences of high temperature, principally enzymatic antioxidants that avoid the cellular damage by a significant reactive species increase. With a low solar irradiance plus self-shading, no UVBR inhibition was present but the UVAR produced a slight 
decrease of cell abundance at $26{ }^{\circ} \mathrm{C}$, being even low at $29{ }^{\circ} \mathrm{C}$ in comparison to the high solar irradiance. Thus, such minimum percentage of cell abundance by UVAR at $29^{\circ} \mathrm{C}$ could be due to a significantly increased protection by CAT activity.

\section{Conclusions}

Global warming enhances water temperatures and thus stratification of water bodies depending on theirs morphometry and wind speed. By reducing the thickness of the upper mixing layer, organisms are more exposed to high UVR doses. According to our results, lower lipid peroxidation of selected UFAs and high capacity of scavenging systems could probably explain the high adaptability of M. aeruginosa to high UVR stress in high temperature conditions. It was evident that selected PUFAs (mostly $\omega 6$ ) play an important role in high temperature adaptation in addition to enzymatic antioxidant increased activity shifting the temperature growth from 26 to $29^{\circ} \mathrm{C}$.

Cell death by UVBR and lipid damage by UVAR were avoided under high temperature acclimation and at high temperature and low solar irradiance due to an increased enzymatic antioxidant activity. Additionally, self-shading may produce a lower SOD, GST and CAT activities compared with decreased abundance.

Extrapolating our results to nature would mean that low irradiance and self-shading may result in lower oxidative stress in M. aeruginosa blooms by reducing effective-light exposure. Further, the increasing global temperature might counteract some of the negative effects of UVBR.

Acknowledgements The research leading to results presented in this publication was carried out with infrastructure funded by EMBRC Belgium-FWO project GOH3817N. The FA analyses were supported by Special Research Fund of Ghent University (BOF-UGent). We acknowledge Dr. Bruno Vlaeminck (UGent) for FA analyses. We especially thanks to Dr. Ferreyra and Dr. Helbling as well as two anonymous reviewers for comments and suggestions. We also thanks Dr. Andrinolo from UNLP for provide the M. aeruginosa strain.

Author contribution All authors contributed to the study conception and design. de la Rosa: writing — reviewing and editing. De Troch: conceptualization, writing - reviewing and editing. Malanga: conceptualization, methodology, visualization, investigation. Hernando: writing - original draft preparation, data curation, supervision, validation, writing-reviewing and editing. All authors read and approved the final manuscript.

Funding Partial financial support was received from Fund of Ghent University (BOF-UGent) in the form of the starting grant 'Energy transfer at the basis of marine food webs in a changing world' awarded to the second author. The authors declare they have no financial interests.

\section{Declarations}

Conflict of interest On behalf of all authors, the corresponding author states that there is no conflict of interest.

\section{References}

1. Fischetti, M. (2013). Deep heat threatens marine life. Scientific American, 308(4), 92. https://doi.org/10.1038/scientificameri can0413-92

2. Previdi, M., \& Polvani, L. M. (2014). Climate system response to stratospheric ozone depletion and recovery. Quarterly Journal of the Royal Meteorological Society, 140(685), 2401-2419. https:// doi.org/10.1002/qj.2330.

3. Bais, A. F., McKenzie, R. L., Bernhard, G., Aucamp, P. J., Ilyas, M., Madronich, S., \& Tourpali, K. (2015). Ozone depletion and climate change: Impacts on UV radiation. Photochemical \& Photobiological Sciences, 14(1), 19-52. https://doi.org/10.1039/c4pp9 $0032 \mathrm{~d}$

4. Tabazadeh, A., Santee, M. L., Danilin, M. Y., Pumphrey, H. C., Newman, P. A., Hamill, P. J., \& Mergenthaler, J. L. (2000). Quantifying denitrification and its effect on ozone recovery. Science, 288, 1407-1411.

5. Bais, A. F., Bernhard, G., McKenzie, R., Aucamp, P., Young, P., Ilyas, M., Jöckel, P., \& Deushi, M. (2019). Ozone-climate interactions and effects on solar ultraviolet radiation. Photochemical \& Photobiological Sciences, 18(3), 602-640. https://doi.org/10. 1039/c8pp90059k

6. Crutzen, P. J. (1992). Ultraviolet on the increase. Nature, 356, 104-105.

7. McKenzie, R. L., Aucamp, P. J., Bais, A. F., Björn, L. O., Ilyasd, M., \& Madronich, S. (2011). Ozone depletion and climate change: Impacts on UV radiation. Photochemical \& Photobiological Sciences, 10, 182-198. https://doi.org/10.1039/c4pp90032d

8. Steinbrecht, W., Hegglin, M. I., Harris, N., \& Weber, M. (2018). Is global ozone recovering? Comptes Rendus Geoscience, 350, 368-375.

9. Häder, D. P. (2011). Does enhanced solar UV-B radiation affect marine primary producers in their natural habitats? Photochemistry and Photobiology, 87, 263-266. https://doi.org/10.1111/j. 1751-1097.2011.00888.x

10. Magee, M. R., \& Wu, C. H. (2017). Response of water temperatures and stratification to changing climate in three lakes with different morphometry. Hydrology and Earth System Sciences, 21(12), 6253-6274. https://doi.org/10.5194/hess-21-6253-2017

11. Calkins, J. (1982). Modeling light loss versus UV-B increase for organisms which control their vertical position in the water column. In: J. Calkins (Ed.), The role of solar ultraviolet radiation in marine ecosystems (Vol. 7). NATO conference series. Boston, MA: Springer.

12. Williamson, C. E., Neale, P. J., Hylander, S., Rose, K., Lopez Figueroa, F., Robinson, S., Häder, D., Wängberg, S., \& Worrest, R. (2019). The interactive effects of stratospheric ozone depletion, UV radiation, and climate change on aquatic ecosystems. Photochemical and Photobiological Sciences, 18(3), 717-746. https:// doi.org/10.1039/c8pp90062k.

13. Chorus, I., \& Bartram, J. (1999). Toxic cyanobacteria in water: A guide to their public health consequences, monitoring and management. London: Routledge.

14. Garcia Pichel, F. (1998). Solar ultraviolet and the evolutionary history of cyanobacteria. Origins of Life Evolution and Biospheres, $28,321-347$. 
15. Palleiro, L., Rodriguez Blanco, M., \& Taboada Castro, M. (2013). The influence of discharge, $\mathrm{pH}$, dissolved organic carbon, and suspended solids on the variability of concentration and partitioning of metals in a rural catchment. Water Air and Soil Pollution, 224, 1-11. https://doi.org/10.1007/s11270-013-1651-9.

16. Qu, H. J., \& Kroeze, C. (2012). Nutrient export by rivers to the coastal waters of China: Management strategies and future trends. Regional Environmental Change, 12(1), 153-167. https://doi.org/ 10.1007/s10113-011-0248-3

17. Paerl, H. W., Hall, N. S., Peierls, B. L., \& Rossignol, K. L. (2014). Evolving paradigms and challenges in estuarine and coastal eutrophication dynamics in a culturally and climatically stressed world. Estuaries and Coasts, 37, 243-258, https://doi.org/10. 1007/s12237-014-9773-x.

18. Giannuzzi, L., Krock, B., Crettaz Minaglia, M. C., Rosso, L., Houghton, C., Sedan, D., Malanga, G., Espinosa, M., Andrinolo, D., \& Hernando, M. (2016). Growth, toxin production, active oxygen species and catalase activity of Microcystis aeruginosa (Cyanophyceae) exposed to temperature stress. Comparative Biochemistry and Physiology Part C, 189, 22-30. https://doi.org/10. 1016/j.cbpc.2016.07.001.

19. Thyssen, M., Ferreyra, G., Moreau, S., Schloss, I., Denis, M., \& Demers, S. (2011). The combined effect of ultraviolet B radiation and temperature increase on phytoplankton dynamics and cell cycle using pulse shape recording flow cytometry. Journal of Experimental Marine Biology and Ecology, 406, 95-107. https://doi.org/10.1016/j.jembe.2011.06.015

20. Häder, D. P., Kumar, H. D., Smith, R. C., \& Worrest, R. C. (2007). Effects of solar UV radiation on aquatic ecosystems and interactions with climate change. Photochemical \& Photobiological Sciences, 6(3), 267-285. https://doi.org/10.1039/c0pp9 $0036 \mathrm{~b}$

21. Alfaro, A. C., Thomas, F., Sergent, L., \& Duxbury, M. (2006). Identification of trophic interactions within an estuarine food web (northern New Zealand) using fatty acid biomarkers and stable isotopes. Estuarine, Coastal and Shelf Science, 70, 271-286. https://doi.org/10.1016/j.ecss.2006.06.017

22. Canganella, F., \& Wiegel, J. (2011). Extremophiles: From abyssal to terrestrial ecosystems and possibly beyond. Naturwissenschaften, 98(4), 253-279. https://doi.org/10.1007/s00114-011-0775-2

23. Hazel, J. R. (1995). Thermal adaptation in biological membranes: Is homeoviscous adaptation the explanation? Annual Review of Physiology, 57, 19-42.

24. Singh, S. C., Sinha, R. P., \& Häder, D. P. (2002). Role of lipids and fatty acids in stress tolerance in Cyanobacteria. Acta Protozool., 41, 297-308.

25. Sato, N., Hagio, M., \& Wada, H. (2000). Environmental effects on acidic lipids of thylakoid membranes. Biochemical Society Transactions, 28, 912-914.

26. Bandyopadhyay, U., Das, D., \& Banerjee, R. K. (1999). Reactive oxygen species: Oxidative damage and pathogenesis. Current Science, 77(5), 658-666.

27. He, Y. Y., \& Häder, D. P. (2002). UV-B-induced formation of reactive oxygen species and oxidative damage of the cyanobacterium Anabaena sp.: protective effects of ascorbic acid and $\mathrm{N}$-acetyl-L-cysteine. Journal of Photochemistry and Photobiology Part B, 66, 115-124. https://doi.org/10.1016/S1011-1344(02) 00231-2.

28. Mozaffarian, D., \& Rimm, E. B. (2006). Fish intake, contaminants, and human health: Evaluating the risks and the benefits. JAMA, 296(15), 1885-1899. https://doi.org/10.1001/jama.296.15. 1885

29. Simopoulos, A. P. (2011). Evolutionary aspects of diet: The omega-6/omega-3 ratio and the brain. Molecular Neurobiology, 44(2), 203-215. https://doi.org/10.1007/s12035-010-8162-0
30. Helbling, E. W., \& Zagarese, H. E. (2003). UV effects in aquatic organisms and ecosystems. Cambridge: The Royal Society of Chemistry.

31. Zinser, E. R., Johnson, Z. I., Coe, A., Karaca, E., Veneziano, D., \& Chisholm, S. (2007). Influence of light and temperature on Prochlorococcus ecotype distributions in the Atlantic Ocean. Limnology and Oceanography, 52, 2205-2220. https://doi.org/ $10.2307 / 4502370$

32. Imlay, J. A. (2003). Pathways of oxidative damage. Annual Review of Microbiology, 57, 395-418. https://doi.org/10.1146/annurev. micro.57.030502.090938

33. Dziallas, C., \& Grossart, H. P. (2011). Increasing oxygen radicals and water temperature select for toxic Microcystis sp. PLoS One, 6(9), e25569. https://doi.org/10.1371/journal.pone.0025569.

34. Saison, C., Perreault, F., Daigle, J. C., Fortin, C., Claverie, J., Morin, M., \& Popovic, R. (2010). Effect of core-shell copper oxide nanoparticles on cell culture morphology and photosynthesis (photosystem II energy distribution) in the green alga, Chlamydomonas reinhardtii. Aquatic Toxicology, 96(2), 109-114. https://doi.org/10.1016/j.aquatox.2009.10.002.D

35. Halliwell, B., \& Gutteridge, J. M. (2007). Free radicals in biology and medicine. New York: Oxford University Press.

36. Dikalow, S. I., \& Harrison, D. G. (2014). Methods for detection of mitochondrial and cellular reactive oxygen species. Antioxidants \& Redox Signaling, 20(2), 372-382. https://doi.org/10.1089/ars. 2012.4886

37. Babele, P. K., Singh, G., Singh, A., Kumar, A., Tyagi, M. B., \& Sinha, R. P. (2017). UV-B radiation and temperature stressinduced alterations in metabolic events and defense mechanisms in a bloom-forming cyanobacterium Microcystis aeruginosa. Acta Physiologiae Plantarum, 39, 248-259. https://doi.org/10.1007/ s11738-017-2540-4

38. Kottuparambil, S., Shin, W., Brown, M. T., \& Han, T. (2012). UV-B affects photosynthesis, ROS production and motility of the freshwater flagellate, Euglena agilis Carter. Aquatic Toxicology, 122, 206-213.

39. Rastogi, R. P., Singh, S. P., Hader, D. P., \& Sinha, R. P. (2010). Detection of reactive oxygen species (ROS) by the oxidantsensing probe $2^{\prime}, 7^{\prime}$-dichlorodihydrofluorescein diacetate in the cyanobacterium Anabaena variabilis PCC 7937. Biochemical and Biophysical Research Communications, 397(29), 603-607.

40. Halliwell, B. (2006). Reactive species and antioxidants. Redox biology is a fundamental theme of aerobic life. Plant Physiology, 141,312-322. https://doi.org/10.1104/pp.106.077073

41. Pérez, G., Doldán, S., Borsani, O., \& Irisarri, P. (2012). Differential response to moderate UV-B irradiation of two heterocystous cyanobacteria isolated from a temperate rice field. Advances in Microbiology, 2, 37-47. https://doi.org/10.4236/aim.2012.21006

42. Rastogi, R. P., Singh, S. P., Incharoensakdi, A., Häder, D., \& Sinha, R. (2014). Ultraviolet radiation-induced generation of reactive oxygen species, DNA damage and induction of UV-absorbing compounds in the cyanobacterium Rivularia sp. HKAR-4. South African Journal of Botany, 90, 163-169. https://doi.org/10.1016/j. sajb.2013.11.006.

43. Wu, H., Gao, K., \& Villafañe, V. E. (2005). Effects of solar UV radiation on morphology and photosynthesis of filamentous cyanobacterium Arthrospira platensis. Applied and Environment Microbiology, 71(9), 5004-5013. https://doi.org/10.1128/AEM. 71.9.5004-5013.2005

44. Hernando, M. P., Crettaz Minaglia, M. C., Malanga, G., Houghton, C., Andrinolo, D., Sedan, D., Rosso, L., \& Giannuzzi, L. (2018). Physiological responses and toxin production of Microcystis aeruginosa in short term exposure to solar UV radiation. Photochemical and Photobiological Sciences, 17(1), 69-80. 
45. Hernando, M. P., Malanga, G. F., \& Ferreyra, G. A. (2005). Oxidative stress and antioxidant defences generated by solar UV in a Subantarctic marine phytoflagellate. Scientia Marina, 69, 287-295.

46. Hernando, M., Schloss, I., Roy, S., \& Ferreyra, G. (2006). Photoacclimation to long-term ultraviolet radiation exposure of natural sub-Antarctic phytoplankton communities: Fixed surface incubations versus mixed mesocosms. Photochemistry and Photobiology, 82(4), 923-935. https://doi.org/10.1562/ 2005-08-29-RA-662

47. Blumthaler, M., \& Webb, A. R. (2003). UVR climatology. In E. W. Helbling \& H. E. Zagarese (Eds.), UV effects in aquatic organisms and ecosystems. Comprehensive series in Photochemical and Photobiological Sciences (pp. 21-58). Cambridge: The Royal Society of Chemistry.

48. Caldwell, M. M., Bornman, J. F., Ballaré, C. L., Flint, S. D., \& Kulandaivelu, G. (2007). Terrestrial ecosystems, increased solar ultraviolet radiation, and interactions with other climate change factors. Photochemical \& Photobiological Sciences, 3, 252-266. https://doi.org/10.1039/b700019g

49. Latifi, A., Ruiz, M., \& Zhang, C. C. (2009). Oxidative stress in cyanobacteria. FEMS Microbiology Reviews, 33(2), 258-278. https://doi.org/10.1111/j.1574-6976.2008.00134.X

50. Liu, Y., Guan, Y., Gao, B., \& Yue, Q. (2012). Antioxidant responses and degradation of two antibiotic contaminants in Microcystis aeruginosa. Ecotoxicology and Environmental Safety, 86, 23-30. https://doi.org/10.1016/j.ecoenv.2012.09.004

51. Boyd, P. W., \& Hutchins, D. A. (2012). Understanding the responses of ocean biota to a complex matrix of cumulative anthropogenic change. Marine Ecology Progress Series, 470, 125-135. https://doi.org/10.3354/meps10121

52. Folt, C. L., Chen, C. Y., Moore, M. V., \& Burnaford, J. (1999). Synergism and antagonism among multiple stressors. Limnology and Oceanography, 44, 864-877.

53. Dunne, R. P. (2010). Synergy or antagonism-interactions between stressors on coral reefs. Coral Reefs, 29, 145-152. https://doi.org/ 10.1007/s00338-009-0569-6

54. Giordanino, M. V., Strauch, S. M., Villafañe, V. E., \& Helbling, E. W. (2011). Influence of temperature and UVR on photosynthesis and morphology of four species of cyanobacteria. Journal of Photochemistry and Photobiology B: Biology, 103(1), 68-77. https://doi.org/10.1016/j.jphotobiol.2011.01.013

55. Gao, K., Li, P., Watanabe, T., \& Helbling, E. W. (2008). Combined effects of ultraviolet radiation and temperature on morphology, photosynthesis and DNA of Arthrospira (Spirulina) plantensis (Cyanophyta). Journal of Phycology, 44(3), 777-786. https:// doi.org/10.1111/j.1529-8817.2008.00512.x

56. Sanchis, D., Carrasco, D., \& Quesada, A. (2004). The genus Microcystis (Microcystaceae/Cyanobacteria) from a Spanish reservoir: A contribution to the definition of morphological variations. Nova Hedwigia, 79(3-4), 479-495. https://doi.org/10.1127/ 0029-5035/2004/0079-0479

57. Karsten, U. (2008). Defense strategies of algae and cyanobacteria against solar ultraviolet radiation. In C. D. Amsler (Ed.), Algal Chemical ecology (pp. 273-296). Berlin, Heidelberg: Springer.

58. Rosso, L., Sedan, D., Kolman, M., Caixach, J., Flores, C., Oteiza, J. M., Salerno, G. L., Echenique, R., Giannuzzi, L., \& Andrinolo, D. (2014). Microcystis aeruginosa strain [D-Leu1] Mcyst-LR producer, from Buenos Aires province, Argentina. Journal of Coastal Life Medicine, 2(4), 287-296. https://doi.org/10.12980/JCLM.2. 2014JCLM-2014-0002.

59. Rippka, R., Deruells, J., \& Waterburry, J. B. (1979). Generic assignments, strain histories and properties of pure cultures of cyanobacteria. Journal of General Microbiology, 111, 1-61.

60. Hernando, M. P., \& Ferreyra, G. A. (2005). The effects of UV radiation on photosynthesis in an Antarctic diatom (Thalassiosira sp.): Does vertical mixing matter? Journal of Experimental Marine Biology and Ecology, 325(1), 35-45. https://doi.org/10. 1016/j.jembe.2005.04.021.

61. Diaz, S., Camilion, C., Deferrari, G., Fuenzalida, H., Armstrong, R., Booth, C., Paladini, A., Cabrera, S., Casiccia, C., Lovengreen, C., Pedroni, J., Rosales, A., Zagarese, H., \& Vernet, M. (2006). Ozone and UV radiation over southern South America: Climatology and anomalies. Photochemistry and Photobiology, 82(4), 834-843. https://doi.org/10.1562/2005-09-26-RA-697.

62. Orce, L. V., \& Helbling, E. W. (1997). Latitudinal UVR-PAR measurements in Argentina: Extent of the "ozone hole." Glob. Planet. Change, 15, 113-121.

63. Abdulkadir, S., \& Tsuchiya, M. (2008). One-step method for quantitative and qualitative analysis of fatty acids in marine animal samples. Journal of Experimental Marine Biology and Ecology, 354(1), 1-8. https://doi.org/10.1016/j.jembe.2007.08.024

64. De Troch, M., Boeckx, P., Cnudde, C., Gansbeke, D., Vanreusel, A., Vincx, M., \& Caramujo, M. (2012). Bioconversion of fatty acids at the basis of marine food webs: Insights from a compoundspecific stable isotope analysis. Marine Ecology Progress Series, 465, 53-67. https://doi.org/10.3354/meps09920

65. Hernando, M. P., Schloss, I. R., Malanga, G., Varela, D. E., \& De Troch, M. (2018). Combined effects of temperature and salinity on fatty acid content and lipid damage in Antartic phytoplankton. Journal of Experimental Marine Biology and Ecology, 503, 120-128. https://doi.org/10.1016/j.jembe.2018.03.004

66. Guckert, J. B., Antworth, C. P., Nichols, P. D., \& White, D. C. (1985). Phospholipid, ester-linked fatty acid profiles as reproducible assays for changes in prokaryotic community structure of estuarine sediments. FEMS Microbiology Ecology, 31(3), $147-158$.

67. Bass, D. A., Parce, J. W., Dechatelet, L. R., Szejda, P., Seeds, M. C., \& Thomas, M. (1983). Flow cytometrie studies of oxidative product formation by neutrophils: A graded response to membrane stimulation. The Journal of Immunology, 130(4), 1910-1917.

68. Malanga, G., Juarez, A. B., Albergheria, J. S., Vélez, C., \& Puntarulo, S. (2001). Efecto de la radiación UVB sobre el contenido de ascorbato y radical ascorbilo en algas verdes. In K. Alveal \& T. Antezana (Eds.), Sustentabilidad de la Biodiversidad, un problema actual, bases científico-técnicas, teorizaciones y proyecciones (pp. 389-398). Concepción: Universidad de Concepción.

69. Malanga, G., \& Puntarulo, S. (1995). Oxidative stress and antioxidant content in Chlorela vulgaris after exposure to ultraviolet-B radiation. Physiologia Plantarum, 94, 672-679.

70. Beutler, E. (1982). Catalase. In E. Beutler (Ed.), Red cell metabolism a manual of biochemical methods (pp. 105-106). New York: GRune and Stratton.

71. Mccord, J., \& Fridovich, I. (1969). Superoxide dismutase. An enzymic function for erythrocuprein (hemocuprein). Journal of Biological Chemistry, 244, 6049-6055.

72. Habig, W. H., Pabst, M. J., \& Jakoby, W. B. (1974). Glutathione S-transferase: The first step in mercapturic acid formation. Journal of Biological Chemistry, 249, 7130-7139.

73. Legresley, M., \& McDermott, G. (2010). Counting chamber methods for quantitative phytoplankton analysis-haemocytometer, Palmer-Maloney cell and Sedgewick-Rafter cell. In: B. Karlson, C. Cusack, \& E. Bresnan (Eds.), Microscopic and molecular methods for quantitative phytoplankton analysis, IOC manual and guides (Vol. 55, pp. 25-30). Paris: Intergovernmental Oceanographic Commission of UNESCO.

74. Scheiner, S. M. (2001). MANOVA: Multiple response variables and multispecies interactions. In S. M. Scheiner \& J. Gurevitch (Eds.), Design and analysis of ecological experiments (pp. 99-115). Oxford: Oxford University Press.

75. Garcia-Pichel, F. (1994). A model for internal self-shading in planktonic organisms and its implications for the usefulness of 
ultraviolet sunscreens. Limnology and Oceanography, 39(7), 1704-1717.

76. Reynolds, C. S. (2006). Ecology of phytoplankton. Cambridge: Cambridge University Press.

77. Barros, M. P., Pedersén, M., Colepicolo, P., \& Snoeijs, P. (2003). Self-shading protects phytoplankton communities against $\mathrm{H} 2 \mathrm{O} 2-$ induced oxidative damage. Aquatic Microbial Ecology, 30(3), 275-282.

78. Girotti, A. W. (2001). Photosensitized oxidation of membrane lipids: reaction pathways, cytotoxic effects, and cytoprotective mechanisms. Journal of Photochemistry and Photobiology B: Biology, 63, 103-113.

79. Zeeshan, M., \& Prasad, S. M. (2009). Differential response of growth, photosynthesis, antioxidant enzymes and lipid peroxidation to UV-B radiation in three cyanobacteria. South African Journal of Botany, 75, 466-474. https://doi.org/10.1016/j.sajb. 2009.03.003

80. Chris, A., Zeeshan, M., Abraham, G., \& Prasaad, S. M. (2006). Proline accumulation in Cylindrospermum sp. Environmental and Experimental Botany, 57(1-2), 154-159. https://doi.org/10. 1016/j.envexpbot.2005.05.008.

81. Bhandari, R., \& Sharma, P. K. (2007). Effect of UV-B and high visual radiation on photosynthesis in freshwater (Nostoc spongiaeforme) and marine (Phormidium corium) cyanobacteria. Indian Journal of Biochemistry \& Biophysics, 44(4), 231-239.

82. Girotti, A. W. (1990). Photodynamic lipid peroxidation in biological systems. Photochemistry and Photobiology, 51, 497-509.

83. Gupta, R., Bhadauriya, P., \& Chauhan, V. (2008). Impact of UVBR on thylakoid membrane and fatty acid profile of Spirulina platensis. Current Microbiology, 56(2), 156-161. https://doi.org/ 10.1007/s00284-007-9049-9

84. Singh, G., Babele, P. K., Sinha, R. P., Tyagi, M. B., \& Kumar, A. (2013). Enzymatic and non-enzymatic defense mechanisms against ultraviolet-B radiation in two Anabaena species. Process Biochemistry, 48, 796-802.

85. Golecki, J. R., \& Drews, G. (1982). Supramolecular organization and composition of membranes. In N. G. Carrand \& B. A.
Whitton (Eds.), The biology of Cyanobacteria (pp. 125-141). Oxford: Blackwell Scientific Publications Ltd.

86. Gombos, Z., Kanervo, E., Tsvetkova, N., Sakamoto, T., Aro, E. M., \& Murata, N. (1997). Genetic enhancement of the ability to tolerate photoinhibition by introduction of unsaturated bonds into membrane glycerolipids. Plant Physiology, 115(2), 551-559.

87. Ehling Schulz, M., \& Scherer, S. (1999). UV protection in cyanobacteria. European Journal of Phycology, 34, 329-338.

88. Thompson, P. J., Harrison, P. J., \& Whyte, J. N. C. (1990). Influence of irradiance on the fatty acid composition of phytoplankton. Journal of Phycology, 26, 278-288.

89. Skerratt, J. H., Davidson, A. D., \& Nichols, P. D. (1998). Effect of UV-B on lipid content of three Antarctic marine phytoplankton. Phytochemistry, 49, 999-1007.

90. Yeagle, P. L. (2014). Non-covalent binding of membrane lipids to membrane proteins. Biochimica et Biophysica Acta, 1838(6), 1548-1559. https://doi.org/10.1016/j.bbamem.2013.11.009

91. Gulei, S., Tiwari, A. (2020). Algae and ageing. In A. Alam, J. L. Xu, \& Z. Wang (Eds.), Microalgae biotechnology for food, health and high value products (Vol. 8, pp. 267-294). Singapore: Springer.

92. Castenholz, R. W., \& Garcia-Pichel, F. (2000). Cyanobacterial responses to UV-radiation. In B. A. Whitton \& M. Potts (Eds.), The ecology of cyanobacteria. Their diversity in time and space (pp. 591-611). Dordrecht: Kluwer Academic Publishers.

93. Bhargava, P., Atri, N., Srivastava, A. K., \& Rai, L. (2007). Cadmium mitigates ultraviolet-B stress in Anabaena doliolum: Enzymatic and Non-enzymatic antioxidants. Biologia Plantarum, 51, 546-550. https://doi.org/10.1007/s10535-007-0118-5

94. Streb, P., Michael-Knauf, A., \& Feierabend, J. (1993). Preferential photoinactivation of catalase and photoinhibition of photosystem II are common early symptoms under various osmotic and chemical stress conditions. Physiologia Plantarum, 88, 590-598.

95. Niyogi, K. K. (1999). Photoprotection revisited: Genetics and molecular approaches. Annual Review of Plant Physiology, 50, 333-359.

\section{Authors and Affiliations}

\section{Florencia de la Rosa ${ }^{1,2,3} \cdot$ Marleen De Troch ${ }^{4} \cdot$ Malanga Gabriela ${ }^{5} \cdot$ Hernando Marcelo ${ }^{6,7}$ (D)}

Hernando Marcelo

mhernando@cnea.gov.ar

1 Instituto de Fisiología y Neurociencias (IFiNe), Universidad de Morón, Buenos Aires, Argentina

2 Machado 914, 5to Piso. (1708), Morón, Argentina

3 CONICET, Godoy Cruz, 2290 Buenos Aires, Argentina

4 Faculty of Sciences, Marine Biology, Ghent University, Krijgslaan 281-S8, Ghent, Belgium

5 Instituto de Bioquímica y Medicina Molecular (IBIMOL), Fisicoquímica, Facultad de Farmacia Y Bioquímica,
Universidad de Buenos Aires (UBA)-CONICET, Junín 956 (C1113AAD), Buenos Aires, Argentina

6 Departamento de Radiobiología, Comisión Nacional de Energía Atómica (CNEA), Centro Atómico Constituyentes, Av. Gral. Paz 1499 (1650) Gral. San Martín, Buenos Aires, Argentina

7 Red de Investigación de Estresores Marinos-Costeros en América Latina y El Caribe, REMARCO, Mar del Plata, Argentina 